\title{
Climate Change Reparations and the Law and Practice of State Responsibility
}

\author{
Benoit MAYER* \\ Institute of International Law and Institute of Environmental Law, Wuhan University Faculty \\ of Law, China \\ bnt.mayer@gmail.com
}

\begin{abstract}
It has been argued elsewhere that industrial states were legally responsible for interfering with the climate system by failing to prevent excessive greenhouse gas emissions. This paper determines the international legal principles relevant to the remedial obligations of industrial states. It assumes that climate change reparations should aim first at providing a signal for the cessation of the wrongful act (i.e. incentivizing climate change mitigation) rather than addressing the injury. A review of state practice in different fields suggests the existence of relevant exceptions to the principle of full reparation. These exceptions relate to the financial capacity of responsible states, the indirect nature of the injury, considerations of "culpability", and the limitations of collective responsibility as "rough" justice. Accordingly, it is suggested that climate change reparations should be limited to partial compensation and symbolic measures of satisfaction prone to incentivize climate change mitigation.
\end{abstract}

Climate change is possibly the greatest harm ever caused by human beings to other human beings - possibly threatening our very existence as a civilization and as a species. ${ }^{\mathrm{I}}$ In recent years, international negotiations, advocacy, and academic research have taken a renewed interest in the relevance of the concept of responsibility in this context, specifically in the relation between industrial states and the developing states most vulnerable to climate change. ${ }^{2}$ In particular, discussions on possible "means to address loss and damage associated with climate change impacts in developing countries that are particularly vulnerable to the adverse effects of climate change" were initiated by the 2007 "Bali Action Plan"; 3

* $\quad$ LLM (McGill), MA Pol Sci. (Sciences Po Lyon); Associate Professor, Wuhan University Institute of International Law, and PhD candidate, National University of Singapore; bnt.mayer@gmail.com. The ideas leading to this paper developed during a visiting doctoral fellowship at the Faculty of Law of the University of Tel Aviv in the winter of $20 \mathrm{I}_{4}-\mathrm{I} 5$, as part of the Global Trust "Sovereigns as Trustees of Humanity" Project. I greatly benefited from comments from, among others, Eyal Benvenisti, Aravind Ganesh, Ayelet Banai, Mikko Rajavuori, Mirjam Streng, Myriam Feinberg, Natalie Davidson, and Sivan Shlomo Agon.

I. See generally, Intergovernmental Panel on Climate Change, Climate Change 2013: The Physical Science Basis, Working Group I Contribution to the Fifth Assessment Report of the Intergovernmental Panel on Climate Change (Cambridge: Cambridge University Press, 20I4) [IPCC 2013].

2. See Benoit MAYER, "Conceiving the Rationale for International Climate Law" (forthcoming) Climatic Change.

3. Decision I/CP.I3 [Thirteen Decision of the First Conference of the Parties to the UN Framework Convention on Climate Change], "Bali Action Plan" (2007), para. (I)(c)(iii). 
the Warsaw International Mechanism for Loss and Damage was established in 20I $4 \cdot{ }^{4}$ As the quest for a comprehensive climate change agreement (where all states would commit to specific commitments) gives a stronger bargaining power to developing states, the demand of the populations most affected by climate change but least responsible for causing it can no longer remain unheard.

International law scholarship certainly has a role to play in this debate. Because international law is essentially a "promise of justice", 5 the moral dimensions of climate change cannot be ignored-in particular as those nations and individuals who benefit the least from industrialization and development are often the most affected by the adverse impacts of climate change. ${ }^{6}$ Beyond the scope of positive rules, there exist general principles underpinning international law, such as the principle of responsibility and some principles governing remedial obligations, from which legitimate expectations arise as to the outcomes of political negotiations, and which therefore should not arbitrarily be disregarded when responses to new issues such as climate change are being imagined. Only if it appears fair to most peoples around the globe can a global climate agreement trigger the costly measures necessary to mitigate climate change. ${ }^{7}$ International law, despite all its flaws and biases, is certainly a strong reflection of broadly accepted moral principles.

Besides, the failure of states to agree on climate change responses in line with general principles of international law would significantly impede the promotion of the rule of law in international relations and trust in international institutions, as it would demonstrate that some (powerful) states can get away with knowingly causing the greatest harm to global commons. As the adverse impacts of climate change are becoming more discernible and far-reaching, a constant haggling of national mitigation commitments would increasingly become an embarrassment for international law-showing just too clearly the incapacity of international law to fulfil its promise of justice when the interests of powerful industrial nations are at stake.

An argument has been made elsewhere ${ }^{8}$ according to which industrial states (in particular) $)^{9}$ are responsible, under international law, for their failure to prevent

4. Decision 2/CP.r9, "Warsaw International Mechanism for Loss and Damage Associated with Climate Change Impacts" (20I4), para. I [Warsaw International Mechanism].

5. Martti KOSKENNIEMI, "What Is International Law for?" in Malcolm D. EVANS, ed., International Law (Oxford: Oxford University Press, 2010), 32 at 32.

6. See generally, International Panel on Climate Change, Climate Change 20I4: Impacts, Adaptation, and Vulnerability: Volume I, Global and Sectoral Aspects, Working Group II Contribution to the IPCC Fifth Assessment Report (Cambridge: Cambridge University Press, 20I4) [IPCC 20I4].

7. This is one of the main conclusions of a workshop convened by the secretariat of the UN Framework Convention on Climate Change (UNFCCC) in 2010. See UNFCCC, "Report on the Workshop on Equitable Access to Sustainable Development", FCCC/AWGLCA/2OI 2/INF.3/Rev.I (20I2), para. 7I.

8. Benoit MAYER, "State Responsibility and Climate Change Governance: A Light through the Storm" (2014) I3 Chinese JIL 539. See also Christina VOIGT, "State Responsibility for Climate Change Damages" (2008) 77 Nordic JIL I; Roda VERHEYEN and Peter RODERICK, "Beyond Adaptation: The Legal Duty to Pay Compensation for Climate Change Damage” (2008) WWF UK.

9. Emerging economies such as China or Brazil account for steadily increasing GHG emissions, although per capita emissions in these countries remain currently several times inferior to the per capita emissions of the US, Australia, Canada, or the EU. The gap is wider when stocks of historical per capita emissions are 
excessive greenhouse gas (GHG) emissions within their jurisdiction. This argument can be based on a breach of the "no harm" principle, from which arises an obligation for states to prevent activities within their jurisdiction that cause cross-boundary environmental damage. ${ }^{10}$ The injury caused by this internationally wrongful act is most persuasively conceived of as an injury to the global atmospheric commons-or, in the terms of the UN Framework Convention on Climate Change, as a "dangerous anthropogenic interference with the climate system". ${ }^{\text {I }}$ The International Law Commission (ILC) recognized that breaches to obligations owed to the international community as a whole could also give rise to an obligation to pay reparations. ${ }^{\mathrm{I} 2}$ Although there is no clear precedent on this, it seems possible to assume, in line with the state-centred nature of international law, that compensation should accordingly be paid to the states representing the populations most affected by the injury caused to the global commons. ${ }^{\text {I3 }}$

However, one cannot ignore the formidable institutional and political obstacles to the implementation of this legal argument. ${ }^{\mathrm{I} 4} \mathrm{~A}$ jurisdictional finding of the responsibility of industrial states is unlikely because of the consensual nature of international adjudication, ${ }^{15}$ the geopolitical settings whereby the states most affected by climate change are also those with the least diplomatic power, ${ }^{\text {I6 }}$ and the fragmentation of

considered. Data on greenhouse gas emissions per country can be accessed, for instance, from the World Resources Institute's Climate Data Explorer, online: <http://cait2.wri.org>.

Io. See in particular, Trail Smelter (United States v. Canada), Decision of I I March I94 I, [I94I] III Reports of International Arbitral Awards 1907 at 1965; Declaration of the United Nations Conference on the Human Environment, UN Doc. A/Conf.48/I 4/Rev.I (I972), principle 2 I [Stockholm Declaration]; Rio Declaration on Environment and Development, UN Doc. A/CONF.I 5 I/26 (vol. I) (I992), principle 2 [Rio Declaration]; The Legality of the Threat or Use of Nuclear Weapons, Advisory Opinion, [I996] I.C.J. Rep. 226 at para. 29; Iron Rhine Arbitration (Belgium v. Netherlands), Decision of 24 May 2005, [2005] XXVII Reports of International Arbitral Awards 35 at para. 222; Pulp Mills on the River Uruguay (Argentina v. Uruguay), [20Io] I.C.J. Rep. I4 at para. IoI; Philippe SANDS and Jacqueline PEEL, Principles of International Environmental Law (Cambridge: Cambridge University Press, 20I2) at I96. Alternative arguments could invoke the failure of a state to comply with its obligations under diverse relevant treaties, including not only the UN Framework Convention on Climate Change, I4 June I992, I77I U.N.T.S. I07 (entered into force 2I March 1994) [UNFCCC], and the Kyoto Protocol to the UNFCCC, II December I997, 2303 U.N.T.S. I48 (entered into force I6 February 2005) [Kyoto Protocol]), but also, among others, the Montreal Protocol on Substances that Deplete the Ozone Layer, I6 September I987, I 522 U.N.T.S. 3 (entered into force I January I989); the Convention on Long-Range Trans-boundary Air Pollution, I 3 November I979, I 302 U.N.T.S. 2 I 7 (entered into force I6 March I983), and its eight protocols; the ASEAN Agreement on Trans-boundary Haze Pollution, Io June 2002 (entered into force 25 November 2003); and the UN Convention on the Law of the Sea, Io December I982, I 833 U.N.T.S. 3 (entered into force I6 November I994), part XII.

II. UNFCCC, supra note Io, art. 2. See also the second recital of the UNFCCC, "[a]cknowledging that change in the Earth's climate and its adverse effects are a common concern of humankind".

I2. Draft Articles on Responsibility of States for Internationally Wrongful Acts, U.N.G.A. Res. $56 / 8$ (200I) [Draft Articles on State Responsibility], art. 42(2) and commentary under art. 42, para. I 2 ("In case of breaches of obligations under article 48 , it may well be that there is no State which is individually injured by the breach, yet it is highly desirable that some State or States be in a position to claim reparation, in particular restitution.”). In the context of climate change, restitution would be materially impossible as it would involve, at least, removing phenomenal quantities of GHG from the atmosphere.

I3. See Mayer, supra note 8, paras. 42-3; Benoit MAYER, "Whose 'Loss and Damage'? Promoting the Agency of Beneficiary States" (2014) 4 Climate Law 267.

I4. See Mayer, supra note 8, paras. 27-3I, 52-63.

I 5. See e.g. Statute of the International Court of Justice, 26 June I 945, [I946] U.K.T.S. 67 (entered into force 24 October I945), art. 36.

I6. Political pressure has already been applied on developing states against legitimate calls for responsibility. For instance, Palau (a small island developing state with a population of about 20,000 ), which initiated a 
responsibility between multiple industrial states. ${ }^{17}$ Even if the responsibility of industrial states, or of some of them, was asserted in a contentious case or (perhaps slightly more likely) through an advisory opinion, absent diplomatic power and effective counter-measures on the side of those most affected by climate change, compliance would entirely depend on the goodwill of political leaders within industrial states.

More fundamentally, political hurdles impede our admission of the responsibility of industrial states for climate change. While climate scepticism is overrepresented in the media, ${ }^{18}$ the very abstract concept of an alteration of the probability of particular weather patterns (rather than the occurrence of a particular weather event) is not easily communicable in the sort of simple political discourses on the basis of which liberal democracies make collective decisions. Because it "lacks a sense of urgency", ${ }^{19}$ climate change, as "creeping normalcy", ${ }^{20}$ has not triggered wide mobilization in support of immediate action.

This paper questions the nature of climate change reparations on the basis of customary international law. It contends that climate change reparations need to be designed with a particular sensitivity to the unprecedented nature of climate change, but that it should also take stock of relevant analogies with state practice in some relevant fields. Accordingly, it opposes a strict application of certain provisions of the law of state responsibility as codified by the International Law Commission. Whereas Article $3 \mathrm{I}(\mathrm{I})$ of the Draft Articles on State Responsibility assesses that a "responsible State is under an obligation to make full reparation for the injury caused by the international wrongful act", ${ }^{2 \mathrm{I}}$ this paper argues that climate change reparations need not (and certainly cannot) be "full" reparations.

Thus, the argument of this paper is two-faceted. On the one hand, it develops new reflections on climate change reparations which, hopefully, will resonate with ongoing

campaign for the UN General Assembly to request an advisory opinion from the ICJ, had to back out when the US threatened to interrupt the provision of development aid. See e.g. Stuart BECK and Elizabeth BURLESON, "Inside the System, Outside the Box: Palau's Pursuit of Climate Justice and Security at the United Nations" (2OI4) 3 Transnational Environmental Law I7 at 26. Likewise, Tuvalu, another small island developing state (population Iо,০০০) highly dependent on international aid, has not carried out its repeated threats to seek the responsibility of Australia or the US before an international jurisdiction.

17. A decision on an apportionment of responsibility, in a contentious case, could be precluded by the Monetary Gold principle, in application of which the ICJ has refused to determine the responsibility of a state if, in order to do so, "it would have to rule, as a prerequisite, on the lawfulness" of the conduct of a third state. East Timor (Portugal v. Australia), [1995] I.C.J. Rep. 90 at para. 35; Monetary Gold Removed from Rome in 1943 (Italy v. France), [I954] I.C.J. Rep. I9 at 32. See also, however, Certain Phosphate Lands in Nauru (Nauru v. Australia), Judgment of 26 June 1992 on preliminary objections, [I992] I.C.C. Rep. 240 at 259-60.

I 8. See Maxwell BOYKOFF and Jules BOYKOFF, "Climate Change and Journalistic Norms: A Case-Study of US Mass-Media Coverage" (2007) 38 Geoforum II90 at II90, observing the media's frequent "adherence to first-order journalistic norms-personalization, dramatization and novelty". See also, generally, Maxwell BOYKOFF and Jules BOYKOFF, "Balance as Bias: Global Warming and the US Prestige Press" (2004) I4 Global Environmental Change I33.

I9. Anthony LEISEROWITZ, "Climate Change Risk Perception and Policy Preferences: The Role of Affect, Imagery, and Values" (2006) 77 Climatic Change 45 at 64. See also Elke WEBER, "Experience-Based and Description-Based Perceptions of Long-Term Risk: Why Global Warming Does Not Scare Us (Yet)" (2006) 77 Climatic Change I03; Harry COLLINS and Robert EVANS, Rethinking Expertise (Chicago: University of Chicago Press, 2007) at 2 (discussing "science's ... short-term political impotence").

20. Jared DIAMOND, Collapse: How Societies Choose to Fail or Succeed (New York: Penguin, 201 I) at 425.

2I. Draft Articles on State Responsibility, supra note I2, art. 3 I(I). 
debates on "loss and damage" associated with climate change impacts in developing countries and with other discussions within the climate regime, as part of a wider project of highlighting the long-overseen relevance of international law to the governance of climate change. On the other hand, based on the example of climate change reparations, it suggests a reflection on the nature of remedial obligations, involving a criticism of the general character of Article $3 \mathrm{I}(\mathrm{I})$ of the Draft Articles on State Responsibility, by showing that states have sometimes consensually rejected full reparation on the basis of certain equitable considerations.

The concept of "climate change reparations" used in this paper hints at an analogy with war reparations, a field where, ever since the devastating experience of the Versailles Treaty, ${ }^{22}$ it appeared that full reparation could be politically toxic. Beyond war reparations or mass atrocities more generally, states have also agreed to less than full reparations in the settlement of trade disputes or in relation to the takings of foreign properties, as well as when loss and damage arise from hazardous activities. The relevance of these different fields cannot be dismissed simply on the ground that they would constitute a lex specialis derogating to the general law of state responsibility: the general practice of states in these fields reflects the consistent recognition of certain transversal justifications for a diminution of reparation.

Consistently, in the context of climate change, a diminution of industrial states' remedial obligations could be justified on the basis of the limited financial capacity of the responsible states, the indirect nature of the injury, the significant disproportion between the injury and the wrongfulness of the act, and the limitation of collective responsibility as a form of "rough" justice in the cases of large injuries. More pragmatically, a prompt admission of responsibility accompanied by a limited payment of reparations would create some political impetus and facilitate efforts to cease excessive wrongful acts, hopefully before current, growing, GHG emissions trigger an irremediable and cataclysmic change in our climate.

The remainder of this paper is structured as follows. Section I provides a general overview of current debates on climate change reparations, as the political context is useful in conceiving the rationale for, and hence the nature of, climate change reparations. Section II retraces the timid recognition of less than full reparation across different fields of international law, with regard to war reparations, trade disputes, expropriations, and hazardous activities. Section III identifies systematically four justifications for a diminution of climate change reparations by analogy with the general practice of states in these different fields. Section IV ponders the implications of less than full climate change reparations for climate change governance as well as international law in general. Section V concludes.

\section{SITUATING CLIMATE CHANGE REPARATIONS}

In order to situate climate change reparations in the context of climate change negotiations, this section introduces general reflections on climate change and responsibility (A), recounts the recent breakthrough of the concept of "loss and damage" (B), before defining the rationale for climate change reparations $(\mathrm{C})$.

22. Versailles Treaty, 28 June I9I9, [I9I9] U.K.T.S. 4 (Cmd I 53) (entered into force 20 January I920), art. 232. 


\section{A. Climate Change and Responsibility}

The idea of a responsibility for environmental damages is certainly not new. Its conceptual roots can be drawn from the Roman maxim "sic utere tuo ut alienum non laedas" ("Use your own property in such a way that you do not injure other people's"), to which domestic provisions on nuisance (in common law) or neighbourhood disturbances (in civil law) relate closely. The Trail Smelter arbitral award stated that: "under the principle of international law ... no State has the right to use or permit the use of its territory in such a manner as to cause injury by fumes in or to the territory of another or the properties or persons therein, when the case is of serious consequence and the injury is established by clear and convincing evidence." ${ }^{23}$ The 1972 Stockholm Declaration of the United Nations Conference on the Human Environment, the 1992 Rio Declaration on Environment and Development, as well as a number of other international instruments, jurisdictional decisions, and teachings of the most highly qualified publicists have confirmed that states have an obligation to ensure that activities within their jurisdiction do not cause damage beyond this jurisdiction (the no-harm principle). ${ }^{24}$

Adopted at The Earth Summit in Rio de Janeiro in June I992, the UN Framework Convention on Climate Change (UNFCC) recalled the no-harm principle, ${ }^{25}$ noting also that "the largest share of historical and current global GHG emissions has originated in developed countries". ${ }^{26}$ However, this preambular reference to the no-harm principle was obscured by the recognition of a new and somewhat mysterious principle of "common but differentiated responsibilities", ${ }^{27}$ in application of which "the developed country Parties should take the lead in combating climate change and the adverse effects thereof". ${ }^{28}$ The nature of the principle of common but differentiated responsibilities remained unclear: while it may seem to hint at the causal responsibility of industrial states (as an application of the no-harm principle), developed states have argued that it only "highlights the special leadership role of developed countries, based on [their] industrial development, [their] experience with environmental protection policies and actions, and [their] wealth, technical expertise and capabilities". ${ }^{29}$ As a reflection of the limits of this constructive ambiguity, the UNFCCC contained only limited ambition on North-South finance..$^{3 \circ}$ Over the last two decades, climate finance has invariably concentrated on climate change mitigation (i.e. the limitation and reduction of GHG emissions and the enhancement of GHG sinks and reservoirs),

23. Trail Smelter, supra note Io.

24. See generally the sources cited supra note ro.

25. UNFCCC, supra note Io, 9 th recital.

26. Ibid., $4_{\text {th }}$ recital.

27. Ibid., 7 th recital, arts. $3(\mathrm{I}), 4(\mathrm{I})$.

28. Ibid., art. 3(I).

29. Written statement of the United States on principle 2 of the Rio Declaration, in UN Conference on Environment and Development, UN Doc. A/CONF.I 5 I/26 vol. II (I992) at I7-I 8.

30. UNFCCC, supra note Io, art. 4(4): "The developed country Parties and other developed Parties included in annex II shall also assist the developing country Parties that are particularly vulnerable to the adverse effects of climate change in meeting costs of adaptation to those adverse effects." This language is different from "meeting the costs of adaptation". 
rather than adaptation (i.e. adjustments in response to the effects or impacts of climate change). ${ }^{3 \mathrm{I}}$ Most of the burden of adapting to the adverse impacts of climate change has remained on the states directly affected, in particular developing states that had only marginally benefited from industrialization. ${ }^{32}$

Overall, words such as "reparation" and "compensation" have remained political non-starters for the representatives of industrial nations, ${ }^{33}$ which have engaged in a systematic effort to derail any principled discussion of the ethical or legal dimensions of climate change. Developed states have thus rejected any discussion on the principles that should guide climate governance, from the early negotiations of the $\mathrm{UNFCCC}^{34}$ to the proposal of India to initiate a dialogue on equity in $20 \mathrm{I}$ I. ${ }^{35}$ The same year, the US used the leverage of its international aid to development and blocked the campaign of Palau, at the UN General Assembly, to request an advisory opinion of the International Court of Justice (ICJ) on the legal aspects of climate change. ${ }^{36}$

Likewise, from 20I I to 20I3, developed states representatives at the Sixth Committee of the UN General Assembly fiercely opposed the inclusion of a topic on the "protection of the atmosphere" within the long-term work programme of the International Law Commission (ILC), ${ }^{37}$ on the (surprising) ground that the existing political process of negotiations were "relatively effective", ${ }^{8}$ had "provided sufficient general guidance to States", 39 and "was already well-served by established legal arrangements". ${ }^{\circ}$ The ILC could only initiate the study of the topic after a costly political compromise that excluded virtually any possible substance from its consideration: it was not only prevented from interfering with negotiations on climate change, but also from dealing with the "liability of States and their nationals, the polluter-pays principle, the precautionary principle, common but differentiated responsibilities, and the transfer of funds and technology to developing countries, including intellectual property rights". ${ }^{4 \mathrm{I}}$ By evading any substantive

3I. See in particular, Barbara BUCHNER et al., Global Landscape of Climate Finance 2014 (San Francisco: Climate Policy Initiative, 20I4); UNFCCC Standing Committee on Finance, 20I4 Biennial Assessment and Overview of Climate Finance Flows (Bonn: UNFCCC, 20I4).

32. See generally, United Nations Environmental Programme (UNEP), The Adaptation Gap Report 20I4: A Preliminary Assessment Report (Nairobi: UNEP, 20I4).

33. See e.g. Koko WARNER and Sumaya Ahmed ZAKIELDEEN, Loss and Damage Due to Climate Change: An Overview of the UNFCCC Negotiations (Oxford: European Capacity Building Initiative, 20I 2 ) at 3.

34. See e.g. Daniel BODANSKY, "The United Nations Framework Convention on Climate Change: A Commentary" (I993) I 8 Yale Journal of International Law 45 I at 50 I.

35. See UNFCCC, Report of the Conference of the Parties on its seventeenth session, held in Durban from 28 November to I I December 20I I, Part One: Proceedings, FCCC/CP/20I I/9, paras. I3-I 8.

36. Beck and Burleson, supra note 16 at 26.

37. International Law Commission, Report of the Sixty-third session (20II), para. 365 and Annex II, Protection of the atmosphere, by Mr Shinya Murase.

38. Statement of Mr Simonoff (United States), in the Summary Records of the 2oth meeting of the Sixth Committee of the UN General Assembly in its 66th session, UN Doc. A/C.6/66/SR.20 (20I I) at para. I 5.

39. Statement of Mr Buchwald (United States), in the Summary Records of the I9th meeting of the Sixth Committee of the UN General Assembly in its 67th session, UN Doc. A/C.6/67/SR. I9 (20I 2) at para. I I 8.

40. Statement of Mr Macleod (United Kingdom), in the Summary Records of the I 8 th meeting of the Sixth Committee of the UN General Assembly in its 68th session, UN Doc. A/C.6/68/SR.I 8 (20I3) at para. 2 I.

4I. Shinya Murase, First Report on the Protection of the Atmosphere, UN Doc. A/CN.4/667 (20I4) at para. 5. This compromise also provides that " $[\mathrm{t}]$ he outcome of the work on the topic will be draft guidelines that do not seek to impose on current treaty regimes legal rules or legal principles not already contained therein". Mr Sinhaseni (Thailand) questioned the 6th Committee: "What would be left for the 
discussion within the ILC, developed states ensured that climate change governance would follow a political logic where power dominates, rather than the guidance of general principles of law and justice.

\section{B. The Recent Breakthrough of the Concept of Loss and Damage}

Despite the hostility of developed states to any discussion of the ethical or legal aspects of climate change, arguments for climate change responsibility have repeatedly been made by the representatives of the most vulnerable states. In I99I, the Alliance of Small Island States (AOSIS) proposed to the Intergovernmental Negotiating Committee for a Framework Convention on Climate Change the establishment of an international insurance mechanism whose revenues would be drawn "from mandatory sources" in developed states, and which would be used "to compensate the most vulnerable small island and low-lying coastal developing countries". ${ }^{42}$ While this submission was limited to "loss and damage resulting from sea level rise", ${ }^{43}$ it recognized that similar mechanisms could eventually be established to cover other adverse impacts that could be attributed to climate change. ${ }^{44}$ The proposal was given little consideration at the time because, as an observer noted, the most vulnerable states "had [little] to offer the developed world in exchange for financial transfers". ${ }^{45}$

The concept of loss and damage came back to the fore in recent years, as developed states were increasingly ready to make some concessions in exchange for mitigation commitments on the part of emerging economies. ${ }^{46}$ In 2007 , as part of an "enhanced action on adaptation", the Bali Action Plan invited consideration of "means to address loss and damage associated with climate change impacts in developing countries that are particularly vulnerable to the adverse effects of climate change" ${ }^{47}$ The discussions initially took place within the Ad Hoc Working Group on Long-term Cooperative Action under the Convention, ${ }^{48}$ where the concept soon appeared to be sidelined in the

Commission to work on that might be of use to the international community?" See Summary Records of the I9th meeting of the Sixth Committee of the UN General Assembly in its 68th session, UN Doc. A/C.6/68/ SR.I9 (2013) at para. 27.

42. Submission by Vanuatu on behalf of AOSIS, "Draft annex relating to Article 23 (Insurance) for inclusion in the revised single text on elements relating to mechanisms (A/AC.237/WG.II/Misc.I3) submitted by the Co-Chairmen of Working Group II" (I99I), reproduced in Intergovernmental Negotiating Committee for a Framework Convention on Climate Change, 4th session, "Elements Relating to Mechanisms", UN Doc. A/AC.237/WG.II/CRP.8 (I99I) 2 at 2, para. I(5).

43. Ibid.

44. Ibid., at 7 (para. a) and 9 (para. i).

45. Bodansky, supra note 34 at 528 .

46. A non-negligible, although purely discursive concession was made when developed states agreed to a text attributing their leading role, resulting from the principle of common but differentiated responsibilities, "to [their] historical responsibility" for climate change. Decision I/CP.I6, "The Cancun Agreements: Outcome of the work of the Ad Hoc Working Group on Long-term Cooperative Action under the Convention" (2010), 2nd recital before para. 36 [Cancun Agreements]. The UNFCCC had noted the historical contribution of developed nations, but it had not made any explicit link with the principle of common but differentiated responsibilities.

47. "Bali Action Plan", supra note 3 at para. I(c)(iii). The provision in a preliminary draft extended to all "vulnerable developing countries". See Draft decision I/CP.I3: Consolidated text prepared by the co-facilitators on agenda item 4 (Report of the co-facilitators of the dialogue on long-term cooperative action to address climate change by enhancing implementation of the Convention), FCCC/CP/2007/ CRP.I (2007), at para. I(c)(iii).

48. "Bali Action Plan", supra note 3 at para. I (chapeau). 
arduous negotiations focusing for the greatest part on climate change mitigation. Consistent with their opposition to a recognition of responsibility, some developed states attempted to "avoid discussions related to proposals around compensation for loss and damage" 49 by proposing an alternative focus on risk management, in particular through risk-sharing mechanisms and disaster risk reduction strategies.

After three years and little progress, the 20 Io Cancun Agreements established a "work programme", assigned to the Subsidiary Body for Implementation, in order, again, "to consider, including through workshops and expert meetings, as appropriate, approaches to address loss and damage associated with climate change impacts in developing countries that are particularly vulnerable to the adverse effects of climate change". ${ }^{\circ}$ The Cancun Agreements also clarified that this work programme would cover "the impacts related to extreme weather events and slow onset events", ${ }^{\text {I }}$ such as "sea level rise, increasing temperatures, ocean acidification, glacial retreat and related impacts, salinization, land and forest degradation, loss of biodiversity and desertification". ${ }^{22}$ The following year, the Durban conference defined three thematic areas for this work programme in order to identify possible measures to be taken under the Convention. ${ }^{53}$

While developed states continued to oppose any reference to "redress" or "compensation", 54 they came slowly to admit that addressing loss and damage requires some financial measures. The I 8 th Conference of the Parties to the UNFCCC in Doha in 2012 agreed that negotiations on loss and damage under the Convention should be concerned, among other things, with "enhancing action and support, including finance, technology and capacity building". 55 The following year, the I9th Conference of the Parties established the Warsaw International Mechanism for loss and damage ${ }^{56}$ and, in the same decision, it "request[ed] developed country Parties to provide developing country Parties with finance, technology and capacity-building". ${ }^{57}$ More recently, financial matters were listed among the questions

49. Warner and Zakieldeen, supra note 33 at 4.

50. Cancun Agreements, supra note 46, para. 26. The work programme was conducted within the Subsidiary Body for Implementation $[S B I]$.

51. Ibid., para. 25 .

52. Ibid., para. 25 , note 3 .

53. UNFCCC, Decision 7/CP.7, "Funding Under the Convention" (200I). These thematic areas are: (I) "Assessing the risk of loss and damage ... and the current knowledge of the same", (2) developing "a range of approaches to address loss and damage", and (3) defining "the role of the Convention".

54. A draft decision text adopted at the 37 th session of the SBI included multiple references to compensation. See UNFCCC SBI, “Approaches to address loss and damage associated with climate change impacts in developing countries that are particularly vulnerable to the adverse effects of climate change to enhance adaptive capacity, Draft conclusions proposed by the Chair", FCCC/SBI/2OI 2/L.44 (2OI2), Annex. Yet, Decision $3 /$ CP.I 8 , adopted on the basis of this draft, contains no reference to compensation. See UNFCCC, Decision 3/CP.I 8, “Approaches to address loss and damage associated with climate change impacts in developing countries that are particularly vulnerable to the adverse effects of climate change to enhance adaptive capacity" (2012) [Approaches to address loss and damage]. Discussions on compensatory financial mechanisms remain generally sidelined in the work programme on loss and damage. See e.g. "Report on the expert meeting to consider future needs, including capacity needs associated with possible approaches to address slow onset events", Note by the Secretariat, FCCC/SBI/2OI3/INF. I4 (I6 October 2013), where a compensatory financial mechanism is addressed in no more than one single sub-paragraph (para. $32(\mathrm{~b})$ ).

55. Approaches to address loss and damage, supra note 54, para. 5 (c).

56. Warsaw International Mechanism, supra note 4, para. I.

57. Ibid., para. I4. 
to be dealt with through a two-year workplan of the Warsaw international mechanism approved by the 2oth Conference of the Parties held in Lima in 2014. ${ }^{58}$ The Warsaw international mechanism is set to be reviewed at the 22nd Conference of the Parties in 2016. ${ }^{59}$ While Article 8 of the Paris Agreement will recall the importance of minimizing and addressing loss and damage, the accompanying decision adopted by the 2Ist Conference of the Parties states that it "does not involve or provide a basis for any liability or compensation". 60

Like the principle of common but differentiated responsibilities, the concept of loss and damage could only break through climate change negotiations on the basis of a constructive ambiguity. On the one hand, some developing countries have promoted the concept of loss and damage on the agenda of climate change negotiations in order to raise awareness of the adverse consequences of climate change in developing countries and to call for some form of reparation. On the other hand, developed states have generally tried to confine the discussion to ways to reduce or avoid loss and damage, for instance through disaster risk reduction. ${ }^{6 \mathrm{I}}$ As such, the vision of loss and damage promoted by developed states essentially replicates ongoing discussions on climate change adaptation with, at most, an increased emphasis on building resilience. ${ }^{62}$

\section{The Rationale for Climate Change Reparations}

Claims for the responsibility of industrial nations for causing climate change have often been denounced as the "fanatic" attitude of fund-thirsty nations, ${ }^{63}$ or as attempts to solve global inequalities instead of "just" addressing climate change. ${ }^{64}$ Yet, instead of an aim of its own, the advocates of climate change reparations often promote climate change reparations as an instrument to foster climate change mitigation and, perhaps,

58. "Initial two-year workplan of the Executive Committee of the Warsaw International Mechanism for Loss and Damage associated with Climate Change Impacts", in Annex II of the Report of the Executive Committee of the Warsaw International Mechanism for Loss and Damage associated with Climate Change Impacts, FCCC/SB/20I4/4 (20I4).

59. Warsaw International Mechanism, supra note 4, paras. 9 and Io.

60. UNFCCC, Decision I/CP.2 I, “Adoption of the Paris Agreement”, para. 52.

6I. See generally, Warner and Zakieldeen, supra note 33.

62. Thus, developed states have sometimes criticized the concept of loss and damage as duplicative of existing efforts on climate change adaptation. See, for instance, Submission of Norway, "Work programme on approaches to address loss and damage associated with climate change impacts in developing countries that are particularly vulnerable to the adverse effects of climate change to enhance adaptive capacity" (2 October 20I 2), reproduced as Paper 2 in UNFCCC Secretariat, "Views and information from Parties and relevant organizations on the possible elements to be included in the recommendations on loss and damage in accordance with decision I/CP. I6", FCCC/SBI/20 I 2/MISC. I 4, I 3 at I4. While the Bali Action Plan (supra note 3 ) and the Cancun Agreements (supra note 46) included loss and damage as part of "enhanced action on adaptation", developing states have constantly claimed that loss and damage should constitute a third pillar beyond mitigation and adaptation. See e.g. "Warsaw establishes international mechanism for loss and damage" (November-December 20I3) 279/280 Third World Resurgence I 5-I 8.

63. See, for instance, US Senate, I05th Cong., I 43 Cong. Rec. S8 I I 7 (25 July I997) (debates on the adoption of the Byrd-Hagel Resolution).

64. Thus, Posner and Weisbach criticize those who "treat climate negotiations as an opportunity to solve some of the world's most serious problems-the admittedly unfair distribution of wealth across northern and southern countries, the lingering harms of the legacy of colonialism, and so forth”. See Eric A. POSNER and David A. WEISBACH, Climate Change Justice (Princeton: Princeton University Press, 20IO) at 5 . 
adaptation. In other words, the proponents of climate change reparations do not wish for huge financial penalties as compensation for the harm already inflicted on them as much as they desire that relevant measures be taken promptly to cease the infliction of similar harms.

Climate change reparations could help foster efforts to mitigate climate change in different ways. By internalizing the negative externalities of GHG emissions in the application of the nascent polluter-pays principle, ${ }^{65}$ they would incentivize a reduction of GHG emissions in industrial nations. Beyond this economic incentive, climate change reparations could constitute a political impetus in favour of climate change mitigation. They would in particular build domestic political support for adequate climate change policies by providing an assessment of the overall impacts of climate change and by informing domestic constituencies. Although advocacy for climate change reparations will not constrain any state to any course of action, it establishes solid cognitive bases on which ethical discourses for climate change mitigation could be constructed. Perhaps most importantly, climate change reparations also need to reaffirm the rule of law by sanctioning the breach of an international obligation, in order to foster compliance in international relations. By contrast, the purely restitutive function of climate change reparations-as an attempt to repair an actual injury - is arguably not, and should not be, the first priority of its advocates.

Climate change reparations need to be designed so that they can fulfil their instrumental and somewhat pragmatic function of promoting climate change mitigation. In this regard, any demand for full reparation is an impediment to the argument for climate change reparation, as it is likely to trigger blank rejection on the part of industrial states. Most obviously, full reparation is unlikely to be politically acceptable on the part of industrial states. Full reparation could fuel political support for climate change denial, an easier stand for many economic lobbies and even industrial states' politicians when the stakes are simply too high to conceive of any possible compromise. Even if it could be imposed, full reparation would risk creating animosity among nations and, in any case, diverting much-needed resources for climate change mitigation policies in industrial nations.

Most importantly, full reparation is not necessary in order to incentivize adequate climate change mitigation. Imposing reparations for past emissions will have little direct consequences on the present conduct of industrial states, except perhaps through diffuse deterrence. Full reparation is not necessary to constitute an appropriate incentive for climate change mitigation, not even regarding current GHG emissions. The economic theory of marginal utility suggests that what determines states' conduct is not the mean cost imposed on all GHG emissions, but the marginal cost of additional GHG emissions- the sanction that would be imposed on that state for the last, avoidable unit of GHG emissions. In more concrete terms, this suggests that the most efficient system of reparations would consist in high sanctions on marginal emissions whose payment could be avoided by taking realistic measures within a given timeframe. ${ }^{66}$

\footnotetext{
65. The polluter-pays principle is not recognized as such in international law as it is in certain domestic laws. See, for instance, Sands and Peel, supra note ro at 228-33.

66. This suggests solutions similar to the "grandfathering" of GHG emissions rights.
} 


\section{THE TIMID RECOGNITION OF LESS THAN FULL REPARATION IN INTERNATIONAL LAW}

Climate change is not the only situation where full reparation does not appear as an opportune settlement of claims for responsibility. Even though Article 3I(I) of the Draft Articles on State Responsibility affirms a general obligation of a responsible state to make full reparation, debates within the International Law Commission recognized the possibility of a diminution of reparations in certain situations (A). A brief review of state practice in several fields suggests elements of a recognition of less than full reparation in customary international law (B).

\section{A. The Position of the International Law Commission}

Article 3 I of the Draft Articles on State Responsibility asserts that a responsible state is under the obligation to "make full reparation for the injury caused by the internationally wrongful act" ${ }^{67}$ Provisions of the Draft Articles on State Responsibility exclude excessive forms of restitution ${ }^{68}$ and satisfaction, ${ }^{69}$ but they do not limit the obligation of a state to make full reparation, in particular through compensation. This clear and unqualified support for full reparation concealed a more lively debate, during the discussion of the topic by the International Law Commission, about what constitutes a just and adequate remedy. In 1959, when the ILC was still focused on state responsibility in the context of the takings of foreign property, Special Rapporteur García Amador recognized "cases and situations in which compensation which does not cover the full value of the expropriated property must be regarded as valid and effective".$^{70}$ At the occasion of a more structured debate on secondary obligations in the mid-I990s, some ILC members contended that "insistence on full reparation could be fraught with consequences for developing nations", ${ }^{7 \mathrm{I}}$ especially those with limited financial capacities. Igor Lukashuk argued that " $[\mathrm{t}]$ he sad experience of the Versailles settlement which had become one of the causes of the later war had shown that [full restitution] was often impossible and even undesirable", suggesting that "a system of partial restitution" could be preferable in certain circumstances. ${ }^{72}$

67. Draft Articles on State Responsibility, supra note I 2 at 3 I.

68. See ibid., art. 35(2), excluding restitution when it would "involve a burden out of all proportion to the benefit deriving from restitution instead of compensation".

69. See ibid., art. $37(3)$, excluding satisfaction when it would "be out of proportion to the injury" or if it would "take a form humiliating to the responsible State".

70. F.V. Garcia-Amador, Fourth report on State Responsibility, in (I959) Yearbook of the International Law Commission, vol. II.I, at para. 89 .

7I. Statement of S. Rao, in Summary Records of the 23I $4^{\text {th }}$ meeting of the International Law Commission, UN Doc. A/CN.4/SR.23 I 4 (I993), at para. 78.

72. Summary Records of the 2392th meeting of the International Law Commission, UN Doc. A/CN.4/ SR.2392 (I995), at para. 3 I (using the word "restitution" in the general sense of "reparation"). See also the statement of C. Tomuschat, in ibid. at para. 37; statement of A. Mahiou, in Summary Records of the 23I 4 th meeting of the International Law Commission, UN Doc. A/CN.4/SR.23 I4 (I996), at para. I9; Summary Records of the 2454th meeting of the International Law Commission, UN Doc. A/CN.4/ SR.I454 (1996), at para. I9. 
In accordance with such suggestions, in the document adopted in a first reading in I996, Draft Article 42(3) precluded measures of reparation that would "result in depriving the population of a State of its own means of subsistence",,$^{73}$ thus paraphrasing a provision of the International Covenant on Economic, Social and Cultural Rights. ${ }^{74}$ In the Commentary, the ILC acknowledged this limitation as the application of "a legal principle of general application". ${ }^{75}$ This provision, however, was deleted during the second reading. States, in their comments on the first reading, had viewed the phrasing of this provision as too vague, hence likely to create "avenues for abuses" ${ }^{6}$ or a "pretext by the wrongdoing State to refuse full reparation". ${ }^{77}$ Some states had, however, clearly supported certain limitations to the obligation to make full reparation, suggesting a more precise provision on the conditions for diminution of reparations instead of the mere deletion of Draft Article $42(3) .^{78}$

The decision of the International Law Commission to delete Draft Article 42(3) in the second reading, and not to try to revise it, certainly had much to do with the legitimate desire of this institution to bring to an end the long-lived project on state responsibility by avoiding difficult issues that appeared of limited direct relevance. ${ }^{79}$ Considering the question in practical terms, special rapporteur James Crawford noted that "there was no reason to fear that the requirement to [make full reparation] would deprive [the responsible] State of its own means of subsistence". ${ }^{80}$ As he contended, "[v]astly greater liabilities of States in the context of international debt arrangements were settled every year than ever arose from compensation payments". ${ }^{81}$ Some members disagreed, in particular Raoul Goco and P.S. Rao, who suggested that any reference to "full" reparation was unnecessary: reparation should, as Rao submitted, just be "as complete as possible" in view of the particular circumstances of each case. ${ }^{82}$

73. Draft Articles on the Responsibility of States for Internationally Wrongful Acts adopted in first reading (I996) Yearbook of the International Law Commission, vol. II.2, at 58 [First Reading of the Draft Articles on State Responsibility].

74. International Covenant on Economic, Social and Cultural Rights, I 6 December I966, 993 U.N.T.S. 3 (entered into force 3 January I976), art. I(2): "In no case may a people be deprived of its own means of subsistence."

75. First Reading of the Draft Articles on State Responsibility, supra note 73, commentary under art. 42, para. 8(a).

76. "Comments and observations received by Governments" (I998) Yearbook of the International Law Commission, vol. II.I, 8 I, at I46 (United States).

77. "Comments and observations received by Governments" (I999) Yearbook of the International Law Commission, vol. II.I, IOI, at IO8 (Japan).

78. See, in particular, "Comments and observations received by Governments" (I998), supra note 76 at I45-6 (United Kingdom); "Comments and observations received from Government” (200I) Yearbook of the International Law Commission, vol. II. I, 33, at 6I-2 (Poland).

79. Thus, the reports of the brief discussions of the question reflect a focus on the necessity of any limitation to the obligation to make full reparation, given the general nature of the project on the responsibility of states and the difficulty in defining a precise limitation to the obligation to make full reparation. See, in particular, the statement of James Crawford in the Summary Records of the $26 \mathrm{I} 3$ th meeting of the International Law Commission (2000), at para. I7.

80. Ibid., para. I8.

8I. Ibid. See also James Crawford's Third Report on State Responsibility (2000) Yearbook of the International Law Commission, vol. II.I, at 3, para. 42: "there is no history of orders for restitution in the narrow sense, or of the award of damages by way of satisfaction, which have threatened to deprive a people of its own means of subsistence".

82. See the Summary Records of the 26 I 5 th meeting of the International Law Commission (2000), at paras. 52,55 . 


\section{B. Less Than Full Reparation in Customary International Law}

In several fields of international relations, less than full reparation has been either accepted, or even actively promoted, as a just and adequate remedy. The recognition of less than full reparation in four particular fields is briefly described: wars and other mass atrocities (I), trade measures (2), expropriations (3), and hazardous activities (4).

\section{Wars and other mass atrocities}

War reparations is an obvious case where less than full reparation is the norm. The Versailles Treaty of $1919,{ }^{83}$ collectively remembered as one of the causes leading to World War II, serves as the example that confirms the rule-the demonstration that war reparations must not be full reparations. ${ }^{84}$ Very limited reparations were requested from the defeated parties after World War II; ${ }^{85}$ to the contrary, in fact, as Germany soon received substantial financial aid from the US under the Marshal Plan. When Germany engaged voluntarily in negotiations with Israel and non-governmental Jewish organizations, no serious demand was made for full reparation; ${ }^{86}$ the resulting agreement recognized the determination of the German government "to make good the material damage" caused by the Shoah (the Holocaust). ${ }^{87}$

Despite numerous conflicts since 1945, there is little practice of reparations being paid at all in such contexts. Christine Gray noted that, in most cases where the UN General Assembly or UN Security Council condemned mass atrocities, no measure of reparation was indicated-partly because of uncertainties as to the scope of remedial obligations, and partly because of a more pragmatic emphasis on cessation and guarantees of non-repetition rather than reparation. ${ }^{88}$ As she notes, "[t]he future conduct of the wrongdoing state is often more important to its victim that any award of compensation for past unlawful action" ${ }^{89}$

The reparations imposed by the UN Security Council upon Iraq for its invasion of Kuwait in 1990 is an interesting exception to the general lenience of states regarding war reparations. This reparations scheme, administered by the UN Compensation Commission, was, however, strongly criticized by the doctrine. ${ }^{9 \circ}$ It was interpreted by

83. Versailles Treaty, 28 June I9I9, [1919] U.K.T.S. 4 (Cmd I 53) (entered into force on 20 January I920), art. 232.

84. Christian TOMUSCHAT, "International Law: Ensuring the Survival of Mankind on the Eve of a New Century: General Course on Public International Law" (200I) 28I Collected Courses of the Hague Academy of International Law at 293.

85. See, in particular, Treaty of Peace with Japan, 8 September 1951, I36 U.N.T.S. 45 (entered into force 5 August I952), art. I4(I).

86. See, for instance, M. SHARETT, I4 March 195 I, cited in N. SAGI, German Reparations: A History of the Negotiations (New York: Magnes Press, 1980), at 55, requesting a sum estimated to represent a quarter of the property that was seized.

87. Bilateral agreement between Germany and Israel, signed in Luxembourg on Io December I952, I62 U.N. T.S. 206 (entered into force 27 March 1953), Ist and 2nd recitals [Luxembourg Agreement].

88. C.D. GRAY, Judicial Remedies in International Law (Oxford: Clarendon Press, I987) at 216-17.

89. Ibid., at 217. Gray notes that the president of Guinea once set aside considerations of the UN Security Council to require Portugal to take some measures of reparation, on the motive that only independence could be an appropriate measure of reparation. See ibid. and (197I) UN Monthly Chronicle No I, para. I8.

90. See, for instance, the discussion in Andrea GATTINI, "The UN Compensation Commission: Old Rules, New Procedures on War Reparations” (2002) I3 European Journal of International Law I6I. 
international jurisdictions as an exception justified only in relation to "breaches of international law of unusual seriousness and extent". ${ }^{\text {I }}$ And yet, even in this case, the overall amount of reparation was limited to thirty percent of the annual value of exports of petroleum and petroleum products from Iraq, a threshold determined by the UN Secretary General on the basis of a rough assessment of "the requirement of the people of Iraq, Iraq's payment capacity ... and the needs of the Iraqi economy". ${ }^{92}$

More recently, the 2000 Algiers Agreement established the Eritrea-Ethiopia Claims Commission (EECC), an arbitral tribunal tasked with asserting reciprocal reparation claims arising from the armed conflict between these two countries. ${ }^{93}$ The two states had very limited payment capacities and they were claiming massive reparations: Ethiopia's initial claims for damages, nearly US\$I 5 billion, was several folds higher than Eritrea's yearly national product. ${ }^{94}$ In this context, the EECC briefly contemplated "to limit its compensation awards in some manner to ensure that the ultimate financial burden imposed on a Party would not be so excessive, given its economic condition and its capacity to pay, as to compromise its ability to meet its people's basic needs". 95 The EECC did not eventually need to limit its compensation awards following its finding of relatively limited and largely balanced damages, resulting only in a net payment by Ethiopia of about US\$ Io million.

\section{Trade measures}

Likewise, in the pursuit of their international commercial relations, states have generally agreed that full reparation was neither their normal practice, nor even a desirable outcome. The "first objective" of dispute settlement in international trade law, according to the World Trade Organization's (WTO's) Dispute Settlement Understanding, "is usually to secure the withdrawal of the measures concerned if these are found to be inconsistent with the provisions of any of the covered agreements". ${ }^{96}$ Accordingly, upon finding a domestic measure inconsistent with an international trade agreement, a Panel or the Appellate Body shall only "recommend that the Member concerned bring the measure into conformity". ${ }^{97}$ International trade law does not generally deal with the injuries resulting from such breaches of trade obligations, and the term "compensation" is used to mean "temporary measures available in the event

9I. Eritrea-Ethiopia Claims Commission, Decision number 7 of 27 July 2007, providing guidance relating jus ad bellum liability, XXVI Reports of International Arbitral Awards I0, at I9, para. 29.

92. Note of the Secretary-General, UN Doc. S/225 59 (I99I), at para. 7. See also U.N.S.C. Res. 705 (I99I), para. 2.

93. Agreement Between the Eritrea and Ethiopia, I2 December 2000, $2 \mathrm{I} 38$ U.N.T.S. 94, art. 5 [Algiers Agreement].

94. See Eritrea-Ethiopia Claims Commission, decision of 17 August 2009, Final Award: Eritrea's Damages Claims, decision of I7 August 2009, XXVI Reports of International Arbitral Awards 505, at 522, para. 18 .

95. Ibid., at para. 22.

96. Understanding on Rules and Procedures Governing the Settlement of Disputes, I 5 April I994, I 869 U.N. T.S. 4 OI (entered into force I January I995), art. 3(7) [DSU].

97. Ibid., art. I9(I). See also Understanding Regarding Notification, Consultation, Dispute Settlement and Surveillance, 28 November I979, GATT Doc L/4907, at 2 I0. 
that the recommendations and rulings are not implemented within a reasonable period of time". ${ }^{98}$

A handful of isolated panel decisions concerning cases of anti-dumping or countervailing duties have, however, recommended the restitution of the duties wrongfully levied, ${ }^{99}$ the last of which (and the only one under the WTO) being the Australia-Automotive Leather II (Article 2I.5-United States) case in $2000 .{ }^{100}$ In the latter case, the retrospective measures, which had not been requested, were vehemently criticized by states' representatives at the occasion of the adoption of the Panel report, ${ }^{\text {IOI }}$ on the grounds that retrospective measures were not only inconsistent with relevant treaty provisions, ${ }^{\text {IO2 }}$ but also "contrary to GATT/WTO custom and practice". ${ }^{\text {Io3 }}$ As the claimant itself, the US, noted, there was "a legitimate basis for not requiring the repayment of recurring subsidies that had been granted in the past", in particular the understanding that "termination of the recurring subsidies programme ha[ve] an enforcement effect that [is] sufficient to accomplish the objective" ${ }^{\text {I04 }}$ of the dispute settlement.

\section{Expropriations}

Whether or not takings of foreign properties are to be considered a "wrongful" act, they have led to similar discussions as to the nature of the compensation obligations of the expropriating state. A broad consensus emerged over the last half century, according to which less than full compensation might be justified in large programmes of nationalization. Thus, long deliberations in the UN General Assembly defined, in elusive terms, a duty to pay "appropriate compensation ... in accordance with international law". ${ }^{\text {105 }}$ Likewise, the Institut de Droit International alluded to "an appropriate balance [to] be assured between the interests of the investor and the public purposes of the State" ${ }^{\text {I06 }}$ The American Law Institute's second restatement of the foreign relations law of the US acknowledged the existence of certain "special circumstances, which it left undefined, that could justify a derogation to full compensation in cases of expropriation. ${ }^{\text {I07 }}$

98. DSU, supra note 96, art. $22(\mathrm{I})$.

99. See M. MATSUSHITA, T. SCHOENBAUM, and P.C. MAVROIDIS, The World Trade Organization: Law, Practice, and Policy (Oxford: Oxford University Press, 2003) at 78; P. GRANÉ, "Remedies Under WTO Law" (200I) 4 Journal of International Economic Law 755.

Iо०. WTO, Australia-Automotive Leather II (Art 2I.5), decision of 2 I January 2000, WT/DS I $26 \mathrm{RW}$, para. 6.42. The Panel's decision was not based on art. I9(I) DSU, but on a similar provision: art. 4.7 of the Agreement on Subsidies and Countervailing Measure, I 5 April I994, I 867 U.N.T.S. I4.

Iо . See Minutes of Meeting of the WTO Dispute Settlement Body on I I February 2000, WT/DSB/M/75, at 5 . The report was criticized by representatives of the United States, Australia, Brazil, Canada, Japan, Malaysia, and the European Union; Hong Kong was the only party supporting its conclusion.

I02. Ibid., at 8 (Japan).

I03. Ibid., at 7 (Canada).

I04. Ibid., at 9 (United States).

I05. U.N.G.A. Res. I803 (XVII) (I962), part I, para. 4.

I06. Institut de Droit International, Tokyo Res. 2013/I, "Legal Aspects of Recourse to Arbitration by an Investor against the Authorities of the Host State under Inter-State Treaties", art. I4(2).

I07. American Law Institute, Second Restatement of the Foreign Relations Law of the United States, para. I 88(2): "In the absence of the conditions specified in Subsection (I), compensation must nevertheless be equivalent to full value unless special circumstances make such requirement unreasonable." See also ibid., 
Clearly, these observations do not support the existence of an obligation to make full reparation in cases of expropriation. A summary review of pre-twentieth-century arbitral litigation evidences a startling gap between claims for compensation and awards, suggesting that full compensation was not the practice. ${ }^{\text {I०8 }}$ As M. Sornarajah noted, " $[\mathrm{t}]$ here is no indication in modern practice of full compensation ever having been paid as compensation for nationalization". ${ }^{\text {ro9 }}$ Since World War II, most investment disputes have indeed been settled through lump-sum agreements providing only partial compensation. ${ }^{\text {I }}$ This practice of lump-sum agreements, however, reflects the possibility for states-including expropriating states that have no direct material interests, but only reputational interests in negotiating-to come to a mutually beneficial agreement.

\section{Hazardous activities}

Of a more direct relevance to climate change reparations is the general reluctance to apply full reparations-or, sometimes, any reparations at all-in relation to transboundary harms arising out of hazardous activities. One of the greatest industrial disasters of the twentieth century, the Chernobyl nuclear accident, led to no claims for reparations, the general understanding being that "priority should be given, in the wake [of the accident], to endeavours of another nature". ${ }^{\text {II }}$

More generally, the International Law Commission could only affirm a general obligation of responsible states to make full reparation after having differentiated the topic of state responsibility from that of state "liability" for the injurious consequences arising out of hazardous activities. ${ }^{\text {II } 2}$ The latter topic included not only ultrahazardous activities involving a low probability of causing disastrous transboundary harm, but also activities highly likely to cause significant transboundary harm ${ }^{\mathrm{II} 3}$ showing that the line between state liability and state responsibility is sometimes particularly thin, to say the least. ${ }^{\text {II }}$ Yet, the ILC identified radically different

Explanatory Note (c): "The law is not settled as to what special circumstances may make the requirement of full value unreasonable."

I08. J.M. SWEENEY, "The Restatement of the Foreign Relations Law of the United States and the Responsibility of States for Injury to Aliens" (I964) I6 Syracuse Law Review 762, at 766.

Io9. M. SORNARAJAH, The International Law on Foreign Investment (Cambridge: Cambridge University Press, 20IO) at $4 \mathrm{I} 7$.

I Iо. See generally, Richard B. LILLICH and Burns H. WESTON, International Claims: Their Settlement by Lump Sum Agreements (Charlottesville: University Press of Virginia, I975); Burns H. WESTON, David J. BEDERMAN, and Richard B. LILLICH, International Claims: Their Settlement by Lump Sum Agreements, I975-I995 (Ardsley: Martinus Nijhoff, I999).

II . Correspondence with the Swedish embassy in London, Io December I987, cited in Philippe SANDS, Chernobyl: Transboundary Nuclear Air Pollution-The Legal Materials (Cambridge: Cambridge University Press, I 988), at 27. See also Alexander KISS, "L'accident the Tchernobyl et ses consequences au point de vue du droit international" (I986) 32 Annuaire français de droit international I 39 at I 5 I-2.

I I 2. (I973) Yearbook of the International Law Commission, vol. II, at I69, para. 39.

I I3. Prevention of Transboundary Harm from Hazardous Activities, (200I) Yearbook of the International Law Commission, vol. II.2, I46, art. 2(a); Draft principles on the allocation of loss in the case of transboundary harm arising out of hazardous activities, in (2006) Yearbook of the International Law Commission, vol. II.2, I I O, commentary under art. I, at para. 2 [Draft principles on the allocation of loss].

I 4. For instance, the International Law Commission has analyzed the Trail Smelter case both as a breach of an obligation from which the responsibility of a state can arise and as the archetypical case of international liability for injurious consequences arising out of acts not prohibited by international law. 
secondary obligations in both topics, putting clearly more emphasis on prevention and harm mitigation than on reparation proper with regard to state liability. ${ }^{\text {II } 5}$

When it did address reparation, the International Law Commission only recognized an obligation for the liable state to provide "prompt and adequate" ${ }^{116}$ compensation, clarifying that this meant that the reparation should not be "grossly disproportionate to the damage actually suffered, even if it is less than full". ${ }^{117}$ A previous working draft of the ILC elaborated on the "principle that the victim of harm should not be left to bear the entire loss", ${ }^{18}$ here again clearly recognizing the existence of "circumstances in which the victim of significant transboundary harm may have to bear some loss". ${ }^{119}$ As will be further discussed below, the degree of "culpability" of the liable state is certainly an element to take into account in assessing the level of reparations. As Phoebe Okowa noted, reparation must "take into account the gravity of the wrongful act, the importance of the obligation breached, and the degree of fault or the wilful intent of the wrongdoer". ${ }^{\text {I }} 0$

\section{JUSTIFICATIONS FOR A DIMINUTION OF CLIMATE CHANGE REPARATIONS}

Without developing a systematic doctrine of less than full reparation in international law in this paper, this section aims at identifying the relevant elements of justification for a diminution of climate change reparations on the basis of the analogues presented above. It suggests that a diminution of climate change reparations could possibly be justified by the limited capacity of responsible states to pay (A), the complex and indirect causal link between excessive GHG emissions and the impacts of climate change (B), the disproportion between the injury and the perceived wrongfulness of excessive GHG emissions (C), and the limits of the theory of collective responsibility (D).

\section{A. Capacity of the Responsible State to Pay}

As mentioned above, the International Law Commission accepted, during the first reading of its project on state responsibility, that reparation shall "[i]n no case ... result in depriving the population of a State of its own means of subsistence". ${ }^{\text {I2I }}$

Regarding the former, see Draft Articles on State Responsibility, supra note I2, commentary under art. I4, at para. I4. Concerning the latter, see the report of the working group on international liability for injurious consequences arising out of acts not prohibited by international law, in (I996) Yearbook of the International Law Commission, vol. II.2, Ioo (Annex I), at I03, general commentary, para. 2 [I996 report on international liability]; Draft principles on the allocation of loss, supra note II 3 at I22, commentary under art. 2, at para. I.

I I 5. See Prevention of Transboundary Harm from Hazardous Activities, supra note I I 3 at I46; Draft principles on the allocation of loss, supra note I 3 , principle 3 (b).

I 16. Draft principles on the allocation of loss, supra note I I3, principle 4.

I I7. Ibid., commentary under principle 4, para. 8 .

I 18 . I996 report on international liability, supra note I I4, art. 2 I.

I I9. Ibid., commentary on art. 2I, para. 4.

I20. Phoebe N. OKOWA, State Responsibility for Transboundary Air Pollution in International Law (Oxford: Oxford University Press, 2000) at 209.

I2I. First Reading of the Draft Articles on State Responsibility, supra note 73 at 58, art. 42(3). 
This provision was only removed in the second reading because it was perceived as prone to favour abusive claims and generally irrelevant to the cases typically brought before international jurisdictions. ${ }^{\mathrm{I} 22}$ But beyond international jurisdictions, international law also has a role to play in guiding political negotiations and in framing collective expectations.

The general practice of states, in particular with regard to war reparations or to the transboundary harms arising out of hazardous activities, indicates a concern not to impose full reparation when this would exceed the payment capacity of a state. ${ }^{\text {I23 }}$ Simply delaying the payment of full reparation based on a plea of necessity or force majeure $^{\mathrm{I} 24}$ is not enough in cases where it represents a great proportion of, or even several times, the gross domestic product of the responsible state. ${ }^{25}$ As Christian Tomuschat noted in his course in the Hague Academy of International Law in 200I, "large-scale damage requires other rules than individual cases of wrongdoing". ${ }^{26}$

It may appear counter-intuitive for industrial states, which developed at the expenses of the global environment, to claim an inability to pay full reparation to least developed states that are severely affected by the adverse impacts of climate change. After all, the recognition of the capacity to pay as a justification for a diminution of reparation was mostly thought of as a defence that developing countries could use against developed ones. ${ }^{\text {I27 }}$ However, given the tremendous variability in diverse assessments of the injuries caused by climate change, which are largely contingent on value-loaded assessment (e.g. the discounting rate applicable to future harms), ${ }^{\mathrm{I} 28}$ the recognition of the capacity of responsible states to pay full reparation should at least serve as a safeguard against excessive claims. The payment capacity of industrial states is not unlimited.

The capacity-to-pay criterion should not be approached as a clear-cut threshold, a test determining whether or not a state is capable of paying reparations in full. In fact, the need for the responsible state to keep sufficient resources to protect the human rights of its population is virtually unlimited. ${ }^{29}$ Yet, protection resources have a diminishing marginal utility: the first resources are essential to protect the most basic needs of the population, whereas additional resources are less immediately necessary. Therefore, consideration of the capacity of industrial states to pay climate change reparations requires an appropriate balancing of interests, which should also take the protection needs of the affected states into account.

\footnotetext{
I22. See supra notes 79-8I and accompanying text.

I23. Such grounds for a diminution of a payment were recognized, just a few years after the adoption of Draft Articles on State Responsibility, by the Eritrea-Ethiopia Claims Commissions; see supra note 94.

I24. See James Crawford's Third Report on State Responsibility, supra note 8I at para. 4I, referring to Russian Indemnity ( I 9 I 2) XI Reports of International Arbitral Awards 42 I, at 443. This case, however, related to a transient inability to pay.

I25. See e.g. supra note 94 .

I 26. Tomuschat, supra note 84 at 293 . Tomuschat further noted that, in the determination of war reparations, "account was always taken of the actual capacity to pay".

I27. See, for instance, supra note $7 \mathrm{I}$.

I 28. See, in particular, William D. NORDHAUS, “A Review of the Stern Review on the Economics of Climate Change” (2007) 45 Journal of Economic Literature 686.

I29. International Covenant on Economic, Social and Cultural Rights, supra note 74, art. 2.I.
} 
Beyond the capacity of industrial states to pay, the capacity of international institutions to make them pay also deserves careful consideration, including from a (pragmatic) legal perspective. It could be counter-productive, and hence undesirable, for a court to "grant vain and useless relief". ${ }^{130}$ In sensitive political contexts where the conduct of the responsible state leaves no doubt that this state will not comply with a judgment requiring full reparation, international jurisdictions might have sensible thoughts about providing a mutually acceptable settlement that stops short of full reparation. ${ }^{\mathrm{I}{ }^{\mathrm{I}}}$ When there is only a tiny political window to bend the conduct of states continually failing to limit domestic GHG emissions and thus causing great and possibly existential harm to the global environment, priority should arguably be the prevention of further harm through climate change mitigation rather than the imposition of expensive reparations. While trembling at the idea of tarnishing the apparent independence of international law from power, international lawyers should not suggest full reparations when the most likely consequence of this suggestion would be to sever international relations, derail ongoing negotiations, and possibly hinder international co-operation on climate change mitigation, thus defeating the primary purposes of international law. ${ }^{\mathrm{I} 2}$

\section{B. Indirect Causation of Individual Harms}

Clear evidence shows that certain extreme weather events have become more frequent in many regions of the world, ${ }^{\mathrm{I} 33}$ and that such trends will increase in the future. ${ }^{\mathrm{I} 34}$ Yet, it remains problematic to attribute any concrete loss and damage to climate change because any given weather event could possibly "have occurred by chance in an unperturbed climate". ${ }^{\mathrm{I} 5}$ In particular, it is virtually impossible to make a clear distinction between "human-caused weather" and "tough-luck weather". ${ }^{136}$ Tools are being developed for a statistical attribution of weather events to climate change (i.e. by estimating the increased likelihood of such events), ${ }^{137}$ but this is difficult to reconcile

I30. Williams v. Garner, 268 So. 2 d. 56 (U.S., La. App. Ist Cir. I972) at 6I.

I3 I. Such considerations are perhaps the explanation for a surprising reasoning of the ICJ regarding the remedial obligations of Serbia, in the case regarding the Application of the Convention on the Prevention and Punishment of the Crime of Genocide (Bosnia v. Serbia), Judgment of 26 February 2007, [2007] I.C.J. Rep. 43, para. 462-5. See discussions in Christian TOMUSCHAT, "Reparation in Cases of Genocide" (2007) 5 Journal of International Criminal Justice 905; Marko MILANOVIĆ, "State Responsibility for Genocide: A Follow-Up" (2007) I 8 European Journal of International Law 669 at 69I (noting that it would have been "far, far better for the Court to provide no explanation at all as to why it was not awarding compensation in this concrete case than for it to give the particular justification that it did").

I32. See, in particular, Charter of the United Nations, 26 June I945, 892 U.N.T.S. I I9 (entered into force 24 October I945), art. I.

133. IPCC, Managing the Risks of Extreme Events and Disasters to Advance Climate Change Adaptation: A Special Report of Working Groups I and II of the Intergovernmental Panel on Climate Change (New York: Cambridge University Press, 20I2) at 8 [SREX]. See also "Summary for Policymakers", in IPCC, supra note I, 3 at 5 .

I34. See SREX, ibid., at I3; "Summary for Policymakers", ibid., at 20.

I35. Dáithí A. STONE and Myles R. ALLEN, "The End-to-End Attribution Problem: From Emissions to Impacts" (2005) 7I(3) Climatic Change 303.

I36. Mike HULME, Saffron J. O’NEILL, and Suraje DESSAI, “Is Weather Event Attribution Necessary for Adaptation Funding?” (2OII) 334 Science 764 at 764 .

I37. See e.g. Pardeep PALL et al., "Anthropogenic Greenhouse Gas Contribution to Flood Risk in England and Wales in Autumn 2000" (201 I) 470 Nature 382 at 382, proposing a "probabilistic event attribution 
with the binary causal attribution generally assumed by the law of state responsibility. Article 3 I of the Draft Articles on State Responsibility defined the obligation to make full reparation in relation to the "injury caused by the internationally wrongful act", ${ }^{13} 8$ which it explained as an exclusion of damage "that is too 'remote' or 'consequential' to be subject of reparation". ${ }^{\text {I } 39}$

Slow-onset environmental changes such as sea-level rise could be more directly attributed to climate change. In any case, however, the actual loss and damage suffered by a population largely depend on social factors, in particular the physical exposure of the population to the environmental event ${ }^{\mathrm{I} 4 \mathrm{O}}$ and their vulnerability to this event. ${ }^{\mathrm{I} 4 \mathrm{I}}$ In a developing world with a growing population, the scientific community has expressed high confidence that "increasing exposure of people and economic assets have been the major cause of long-term increases in economic losses from weather- and climate-related disasters". ${ }^{42}$ No clear influence of climate change on loss and damage from disasters could generally be demonstrated over the past decades, ${ }^{\mathrm{I} 3}$ and some studies suggest that the statistical "signal" of climate change could generally remain concealed behind more important changes in exposure and vulnerability in the decades to come. ${ }^{\mathrm{I} 44}$

A pragmatic interpretation of the law of state responsibility suggests that neither full reparation for all weather-related or climate-related loss and damage, nor no reparation at all, would be an adequate remedy for the indirect impacts of climate change. ${ }^{\mathrm{I} 5} \mathrm{~A}$ parallel can be drawn with precedents where partial reparation was indicated for indirect or not fully foreseeable injuries. Thus, in the 1928 Naulilaa case, an Arbitral Panel considered that Germany should have anticipated that its attack on some Portuguese colonies would likely expose Portugal to further turmoil in an unstable colonial context, although

framework"; HUGGEL et al., "Loss and Damage Attribution" (2013) 3 Nature Climate Change 694; Myles ALLEN et al., "Scientific Challenges in the Attribution of Harm to Human Influence on Climate" (2006) I 55 University of Pennsylvania Law Review I353. For a critique of this methodology, see, in particular, Hulme et al., supra note I36.

I38. Draft Articles on State Responsibility, supra note I2, art. 3 I(I).

I39. Ibid., commentary under art. 3 I, para. Io.

I40. Exposure can be defined as " $[\mathrm{t}]$ he presence of people, livelihoods, species or ecosystems, environmental functions, services, and resources, infrastructure, or economic, social, or cultural assets in places and settings that could be adversely affected". See "Summary for Policymakers", in IPCC 20I4, supra note 6 at 5 .

I4I. Vulnerability is "[t]he propensity or predisposition to be adversely affected". It "encompasses a variety of concepts and elements including sensitivity or susceptibility to harm and lack of capacity to cope and adapt". See ibid.

I42. See "Summary for Policymakers", IPCC 2013, supra note I at 9. See also Huggel et al., supra note I 37 at 695 .

I43. "Summary for Policymakers", IPCC 2013, supra note I at 9; Laurens M. BOUWER, "Have Disaster Losses Increased Due to Anthropogenic Climate Change?" (2010) 92 Bulletin of the American Meteorological Society 39.

I44. See, in particular, Laurens M. BOUWER, "Projections of Future Extreme Weather Losses Under Changes in Climate and Exposure" (2013) 33 Risk Analysis 9I 5, noting that "the signal from anthropogenic climate change is likely to be lost among the other causes for changes in risk, at least during the period until 2040".

I45. Precedents in international law, varying between a requirement of "direct", "foreseeable", or "proximate" causal relation, leave ample room for such a pragmatic interpretation. In fact, the ILC itself stated that "the question of remoteness of damage is not a part of the law which can be satisfactorily solved by search for a single verbal formula". Draft Articles on State Responsibility, supra note I 2, commentary under art. 3 I, at para. Io. 
Germany could not have foreseen the nature and extent of the turmoil that would unfold. On this basis, the Panel condemned Germany to the payment of an "equitable additional compensation" ${ }^{146}$ established ex aequo et bono. ${ }^{\mathrm{I} 7}$ Likewise, the settlement of international disputes through diplomatic negotiations has often led to the conclusion of lumpsum agreements representing, in most cases, only a tiny fraction of complex injuries. ${ }^{\mathrm{I} 8}$

\section{Disproportion of the Injury to the "Culpability" of the Responsible State}

International law remedies aim at sanctioning a violation of an international obligation and at repairing the resulting injury. International law remedies need to fulfil these two functions concomitantly rather than alternatively. ${ }^{\text {I49 }}$ Thus, punitive damageswhereby remedies would impose a sanction beyond the reparation of the injury-have generally been rejected in international law. ${ }^{150}$ Likewise, less than full reparation should arguably be indicated when there is a gross disproportion between the degree of "culpability" of the responsible state and the extent of the injury-that is to say, in cases where a "less culpable" (e.g. inadvertent) conduct causes large-scale injuries. ${ }^{\text {I } 5 \text { I }}$ In such cases, a complete transfer of the burden of the injury onto the responsible state could appear excessive $\mathrm{I}^{\mathrm{52}}$ and politically unacceptable, hence unlikely to be enforced, and resort is necessary to an equitable distribution of the burden of the injury between responsible and injured states.

In this sense, Phoebe Okowa suggested in her authoritative study of state responsibility for transboundary air pollution that "pecuniary compensation should in addition to repairing the harm done take into account the gravity of the wrongful act, the importance of the obligation breached, and the degree of fault or wilful intent of the wrongdoer". ${ }^{53}$ Similar considerations were instrumental in the decision of the International Law Commission to single out the question of state "liability" for the harms arising out of hazardous activities, and to define a regime of less than full reparation. ${ }^{\mathrm{I} 4}$ When the working group of the ILC proposed a list

I46. Responsabilité de l'Allemagne à raison des dommages causés dans les colonies portugaises du sud de l'Afrique (Portuval v. Germany), decision of 3 I July I928, II Reports of International Arbitral Awards IOI I, IO3 2-3 [translated by the author].

I47. Ibid., decision of 30 June I930, II Reports of International Arbitral I035, at I074.

I48. See Section III.C.

I49. See Draft Articles on State Responsibility, supra note I2, commentary under art. 36, para. 3, noting that the prevailing view is that "the consequences of an internationally wrongful act cannot be limited either to reparation or to a 'sanction"”. See also R. AGO, "Le délit international” (I939) 68 Collected Courses of the Hague Academy of International Law 4I7 at 430-40.

I 50. See, in particular, Draft Articles on State Responsibility, supra note I 2, commentary under art. 36, para. 4; James CRAWFORD, State Responsibility: The General Part (Cambridge: Cambridge University Press, 20I3) at 523-6; Inter-American Court of Human Rights, Velásquez Rodríguez Case, Judgment of 2I July I989 on compensatory damages, Series C, No. 7, at para. 38.

I 5 I. See e.g. the statement of P.S. RAO in the Summary Records of the 2399 th meeting of the International Law Commission, UN Doc. A/CN.4/SR.2399 (I995), at para. 24.

I 52. Tomuschat, supra note 84 at 296-7.

I 53. Okowa, supra note I 20 at 209.

I54. See supra notes II6-I7 and accompanying text. Nothing would have prevented the ILC from approaching the strict liability regime regulating hazardous activities as primary rules (an obligation of result to prevent a disaster from occurring) subject, in case of breach (i.e. the occurrence of a disaster), to the general regime of state responsibility. See, in this sense, the statement of S. Fomba in the Summary 
of relevant elements on the basis of which the nature and extent of reparations could be negotiated, it put a certain emphasis on the "culpability" of the liable state-for instance whether the liable state had taken appropriate prevention measures and measures to minimize the harm, including through providing assistance to the affected states, and whether it had shared the benefits drawn from the hazardous activity with other states. ${ }^{55}$ The degree of "culpability" of the responsible state was also taken into account in other fields, and could, for instance, contribute to explaining the limitation of reparations for breaches of trade commitments (to which less moral significance is attached than, say, to human rights obligations). ${ }^{\text {I }} 6$

This line of argument applies most straightforwardly to historical GHG emissions, in particular those predating the emergence of a scientific consensus on the anthropogenic causes of climate change. Here again, no clear line can be drawn as scientific evidence accumulated progressively, from the early i96os until the early I990s. ${ }^{\text {I57 }}$ Adopted in 1992, the UN Framework Convention on Climate Change recognizes a clear general scientific consensus that human activities would have consequences, possibly disastrous, on the climate system. ${ }^{15^{8}}$ There is a compelling argument for discounting reparations for the adverse consequences caused by excessive GHG emissions before the emergence of this scientific consensus, in particular before the appearance of any scientific evidence at all. No wrong can reasonably be found when large amounts of GHG were emitted without any possible knowledge of the harmful consequences, when the dominant worldview considered nature as fundamentally inalterable. For this historical period before the emergence of scientific evidence of anthropogenic climate change, reparations could only be justified, perhaps, on the equitable ground of unjust enrichment. However, as a scientific consensus was emerging about anthropogenic climate change, interference with the climate system ceased to be purely accidental; it became at best inadvertent, negligent, and arguably now grossly negligent. Therefore, as a consequence of scientific progress, a greater degree of "culpability" should be attached to present emissions than to past ones, and a diminution of climate change reparations can more readily be justified in relation to past GHG emissions than to present ones.

Records of the 24 I 4 th meeting of the International Law Commission, UN Doc. A/CN.4/SR.24 I 4 (I995), at para. 36; and the statement of Bennouna in the Summary Records of the 245 oth meeting of the International Law Commission, UN Doc. A/CN.4/SR.2450 (I996), at paras. 28-9, 33.

I 55. I996 report on international liability, supra note I I 4, art. 22.

I 56. See also, more generally, the statement of P.S. Rao in the Summary Records of the 26I 5 th meeting of the International Law Commission, UN Doc A/CN.4/SR.26I 5 (2000), at para. 55, arguing that "intentional wrongs and other aspects" need to be factored into the determination of reparation in each particular case.

I 57. Charles Keeling detected a rise in the atmospheric concentration of carbon dioxide in I960, thus confirming the possibility of earlier theories (some from the nineteenth century) of an anthropogenic increase of the greenhouse effect that would alter climatic conditions. In I979, a US National Academy of Sciences report considered anthropogenic climate change as highly credible. See generally, Spencer WEART, The Discovery of Global Warming, 2nd ed. (Cambridge, MA: Harvard University Press, 2008).

I 58 . See UNFCCC, 3 rd recital, noting that: "human activities have been substantially increasing the atmospheric concentrations of greenhouse gases, that these increases enhance the natural greenhouse effect, and that this will result on average in an additional warming of the Earth's surface and atmosphere and may adversely affect natural ecosystems and humankind.” 
"Culpability", moreover, is largely a function of public perception. An additional line of arguments for a diminution of climate change reparations relates to the fact that no state is completely "innocent". ${ }^{159}$ Some states produce more GHG than others, but this has much more to do with differences of development level than to a systematic engagement with the protection of the global environment. It is overwhelmingly considered as a desirable public policy objective for a state to develop its industrial sector, which almost inevitably results in large-scale GHG emissions. Substantive efforts have, however, been made to reduce the carbon intensity of such activities, and some differences exist among developed states, but, for now at least, efforts appear much more clearly in the trends (a diminution or a limitation of the increase of GHG emissions in states making costly efforts to mitigate climate change) than in absolute levels of emissions. This suggests that, if climate change reparations are mostly designed to provide a political or economic signal for climate change mitigation, and if that is yet to be politically acceptable, it is more important to attach consequences to the evolution of GHG emissions than to the absolute levels of emissions in each state.

\section{Limits of Collective Responsibility}

Instances of large reparations also raise questions relating to the limits of the liability of a state-that is, fundamentally, of a people-for the deeds of a government, past or incumbent. The legal personality of the state is a legal fiction: the actions and omissions attributed to "the state" always result from the decisions of a small group of individuals assumed to act on behalf of a people, who have a responsibility to ensure that "the state" respects "its" obligations under international law. ${ }^{160}$ In order to avoid abusive claims that could nullify the very foundation of international law, the legal fiction of the state needs to result in a very strong presumption that the conduct of a government acts on behalf of its state, and that the acts of the government engage the responsibility of the state. In this sense, it is understood that the conduct of a state organ or agent can be attributed to a state notwithstanding the possibility of an excess of authority under domestic laws ${ }^{16 \mathrm{I}}$ or an international criminal responsibility of the individual under international law, ${ }^{162}$ provided only that this organ or agent acted in its official quality.

I 59. By analogy, Pierre-Marie Dupuy once suggested that the limitation of international responsibility for catastrophic damages arising out of hazardous activities was related to a "a diffuse feeling of shameful solidarity between states in front of the degradation of a human environment to which they all contribute" [translated by the author]. Pierre-Marie DUPUY, "L'État et la reparation des dommages catastrophiques" in Francesco FRANCIONI and Tullio SCOVAZZI, eds., International Responsibility for Environmental Harm (London: Graham and Trotman, I99I), I 25 at 142.

I60. See, in particular, Philip ALLOTT, "State Responsibility and the Unmaking of International Law” (I988) 29 Harvard International Law Journal I at I 4, arguing that "[ $t$ ]he wrongful act of a State is the wrongful act of one set of human beings in relation to another set of human beings". See also the Judgment of the International Military Tribunal, in Trial of the Major War Criminals Before the International Military Tribunal, Nuremberg, I4 November I945-I October 1946, vol. I (I947) at 223, noting that "[c]rimes against humanity are committed by men, not by abstract entities".

I6I. See Draft Articles on State Responsibility, supra note I2, art. 7.

I 62. See, in particular, the Rome Statute of the International Criminal Court, I 7 July I 998, 2 I 87 U.N.T.S. 90 (entered into force I July 2002), art. 25(4); Application of the Convention on the Prevention and Punishment of the Crime of Genocide, supra note I3 I at 43, para. I73. See also A. CASSESE, "When May Senior State Officials Be Tried for International Crimes? Some Comments on the Congo v. Belgium Case" 
Nevertheless, it is sometimes necessary to look beyond the legal fiction of the personality of the state, in particular when reparation would otherwise have grossly excessive consequences on the individuals. While collective responsibility is an acceptable form of "rough" justice when the stakes are small, it becomes obviously unfair when it is extended to system-wide violations, whether the latter are inadvertent, negligent, or even when they result from the wilful action of a state's government. The limitations of war reparations since the Versailles Treaty, in particular, reflect a sense that it is not desirable to push the legal fiction of the personality of the state so far as to impose the payment of reparations on the population of devastated states (as a people often suffers when its government wrongfully engages in a war), or to condemn this state to protracted payments of reparations that will affect yet unborn generations. ${ }^{\text {I63 }}$ Beside the moral aspects, the experience of the Versailles Treaty shows that such a rigid application of the principle of state responsibility can be politically toxic, with adverse impacts on domestic public order as well as on international peace and security.

These reflections are perhaps best theorized in relation to a constitutive limitation of the mandate of any government, under the social contract, to represent its people and to commit itself to particular obligations toward other peoples. ${ }^{\text {I64 }}$ Through the recognition of the international criminal responsibility of individuals, ${ }^{165}$ the rejection of the concept of international crimes of states, ${ }^{166}$ and the research of targeted or "smart" economic sanctions that impact a government without affecting its population, ${ }^{167}$ state practice and the legal doctrine have increasingly turned to acknowledge the possibility for international institutions to look beyond the fiction of state responsibility when ascribing responsibilities for breaches of international obligations. International law has recognized that the social contract through which governments arise does not transfer absolute powers upon the latter; limitations of governmental powers include respect for human dignity ${ }^{168}$ as well as environmental sustainability. ${ }^{169}$ Accordingly, a government cannot be deemed to have received an unlimited mandate

(2002) I3 European Journal of International Law 853 at 864; A. NOLLKAEMPER, "Concurrence Between Individual Responsibility and State Responsibility in International Law" (2003) 52 International and Comparative Law Quarterly 6I 5 .

I63. See Section II.B.2.

I64. In contrast to the excess of authority of a state organ or state agent (which does not prevent the attribution of a conduct to the state), the circumstances discussed here relate to an excess of power by a government as a whole. The case-law and doctrine developed in relation to the former do not automatically apply to the latter.

165. See, in particular, Draft Articles on State Responsibility, supra note I2, art. 58; and generally Rome Statute, supra note I62.

I66. See discussion in James Crawford's First Report on State Responsibility, (1998) Yearbook of the International Law Commission, vol. I.I, at 9-24, paras. 43-95. See also XXII Trial of the Major War Criminals before the International Military Tribunal, Nuremberg at 466: "Crimes against international law are committed by men, not by abstract entities, and only by punishing individuals who commit such crimes can the provisions of international law be enforced."

I67. See e.g. D.W. DREZNER, "Sanctions Sometimes Smart: Targeted Sanctions in Theory and Practice" (20II) I 3 International Studies Review 96.

I68. See generally, Universal Declaration of Human Rights, GA Res. 2I7(III); International Covenant on Economic, Social and Cultural Rights, supra note 74; International Covenant on Civil and Political Rights, I6 December 1966, 999 U.N.T.S. I7 I (entered into force 23 March 1976).

I69. See e.g. Rio Declaration, supra note Iо; Stockholm Declaration, supra note Io; UNFCCC, supra note io. 
to commit the worst crimes or to damage the environment of present and future generations, while sending the bill to its people-including to yet unborn generationswithout providing them with any equivalent benefits.

A diminution of climate change reparations could be justified on such grounds, especially in relation to past emissions. The current and future generations of developed states' citizens assume no control for the failure of the past governments of their state to regulate GHG emissions. ${ }^{170}$ Current and future generations may benefit from the development achieved by their ancestors, but this benefit often extends beyond national borders in complex ways that are difficult to assess. Likewise, future generations of citizens in industrial states should not be required to pay full reparation on the ground of current emissions, unless and inasmuch as they can be shown to receive a distinct benefit from present emissions in their state. By contrast, collective responsibility applies more readily in relation to present emissions and present generations. It remains true, however, that a great proportion of current GHG emissions are path-dependent: they are considerably influenced by decisions made years or decades before, for instance regarding transport or energy infrastructures. ${ }^{\mathrm{II}}$ More clearly than past emissions, current emissions can credibly be assumed to benefit current generations at least at the collective level (e.g. through domestic production), and the imposition of a correlative collective cost could therefore be justified.

A symmetrical issue appears, however, at the stage of compensating harms that, for the most, will be suffered by yet unborn generations. ${ }^{172}$ This raises questions relating to the limitation of the legal personality of the state, specifically its ability to represent unborn generations of nationals over decades, centuries, and millennia. Related intractable issues were raised by economists about a possible discount rate to apply in order to assess the present value of future injuries. ${ }^{173}$ Arguably, only part of the injury can be compensated to the government of affected states, based on a role of promoting at least the possibility of the existence of future generations and, perhaps, what can reasonably be assumed to be the interests of these future generations. An argument could consistently be made according to which reparations should not be used exclusively for the benefit of current generations, but also with great concern for sustainable development policies, such as environmental protection, assumed to be in the interest of future generations.

I70. This is certainly the basis for Posner and Weisbach's assertion that collective responsibility for climate change can only rely on "collectivist habits of thinking that do not survive scrutiny". See Posner and Weisbach, supra note 64 at I 6 .

I7I. See, for instance, Marc FLEURBAEY et al., "Sustainable Development and Equity" in O. EDENHOFER et al., eds., Climate Change 20I4: Mitigation of Climate Change, Contribution of Working Group III to the Fifth Assessment Report of the Intergovernmental Panel on Climate Change (Cambridge: Cambridge University Press, 2OI5) 283 at $3 \mathrm{I}_{2}-\mathrm{I} 3$.

172. Even if all anthropogenic GHG emissions ceased today (extremely unlikely because of paths accepted by our generation that almost necessarily engage next generations to keep on with unsustainable practices), the climate would continue to change for many centuries until a new global equilibrium could be reached. Continuing sea-level rise in the coming centuries will, for instance, almost inevitably flood most of the cultural heritage of mankind. See, for instance, Deliang BRUAER et al., "Introduction", IPCC, supra note I, II9 at I28-9.

I73. See Nordhaus, supra note I28. 
Although certain limitations of collective responsibility should be admitted for past, system-wide, wrongful conduct, all forms of collective responsibility do not fade away. The experience of reparations for wars and other mass atrocities suggests that current generations retain some responsibility for what was done in their name, ${ }^{174}$ as the strong presumption of the government's legitimacy cannot disappear without leaving any trace, and, in some cases, because of some possible benefits drawn by the people as a result of the conduct. ${ }^{\mathrm{I} 75}$ However, remedial obligations in such circumstances are of a different nature than in classical cases of the responsibility of a people for the acts and omissions of the government acting in the pursuit of its interests. Rather than an obligation to make full reparation, the responsibility of a people for the illegitimate conduct of its government needs to be tailored through specific negotiations, taking into account the urgency of guarantees of cessation and non-repetition, the requirement that the people of the responsible state draws no unjust benefit from the wrongful act, as well as, more pragmatically, the need to restore constructive and friendly relations between peoples. In this regard, reparations may take multiple forms, including not only material compensation, but also-and overall-symbolic measures such as an apologetic policy of acknowledgment, memory, and commemoration. ${ }^{176}$

\section{IMPLICATIONS FOR CLIMATE CHANGE GOVERNANCE AND GENERAL INTERNATIONAL LAW}

The above considerations of complementary justifications for a diminution of climate change reparations have implications not only for climate change governance (A), but also for our conception of remedial obligations in general international law (B).

\section{A. Implications for Climate Change Governance}

As argued above, there are strong legal arguments for a diminution of climate change reparations. First, climate change reparations should be assessed on the basis of a balancing of the interests of the states affected by climate change, of the responsible states, and of the good administration of justice. Second, given the complexities in assessing and valuing the injury caused by excessive GHG emissions, climate change reparations could only be established ex aequo et bono through some kind of lump-sum agreement, rather than on the basis of a detailed assessment of the injury. Third, an argument could be made for a diminution of reparations due in relation to

I74. See Statement of Chancellor Konrad Adenauer to the Bundestag on 27 September I95 I concerning the attitude of the German Federal Republic toward the Jews, reproduced in C.C. SCHWEITZER, ed., Politics and Government in Germany, I944-I994: Basic Documents (Providence: Berghahn, I995), at I23: "The unmentionable crimes committed in the name of the German people demand a moral and material restitution" [emphasis added]. Adenauer thus insisted that these crimes were committed despite the opposition of the majority of the Germany people.

I75. This would apply for instance to confiscation of the Amerindian or Palestinian lands, from which peoples draw a benefit even in the absence of any personal responsibility.

176. See generally, Elazar BARKAN, The Guilt of Nations: Restitution and Negotiating Historical Injustices (New York: Norton, 2000). A parallel can be drawn with measures promoting education on climate change. See infra note 184 . 
historical emissions, on the ground of the limited "culpability" of polluting states at a time when there was only limited evidence of the adverse consequences of excessive GHG emissions. Fourth, the fiction that the state is responsible for the deeds of its government should not stretch to suggest excessive consequences on individuals, in particular through requiring that a people pays full reparation for historical wrongs resulting in mass injuries through instalments over a long period of time.

From the perspective of historical emissions, this suggests significant diminution of climate change reparations, especially if no distinct present benefit can be identified for the responsible state or its population. ${ }^{177}$ But these considerations also plead for a diminution of climate change reparations on the ground of the continuing failure of states to prevent excessive GHG emissions. The level of climate change reparations should not be asserted solely on the ground of the injury, but also in relation to the need for sanction and by taking the situation of the responsible states duly into account. The indirect nature of the harm caused through excessive GHG emissions and the widespread failure of states to prevent such emissions suggest that full reparation would be disproportionate to the "culpability" attached to states' wrongful conduct.

Climate change reparations should therefore be significantly lower than the valuation of the harm that it causes. Nevertheless, climate change reparations should not be reduced to a trivial payment of "environmental indulgences" through an institutional practice of "selling rights to destroy nature" ${ }^{178}$ Rather, climate change reparations should constitute a sufficient incentive for urgent climate change mitigation policies. It is thus necessary, at the very least and in very abstract terms, that the cost immediately imposed on a state for its failure to prevent marginal GHG emissions exceeds the interest that it attaches to these marginal GHG emissions, so that each state is incentivized to reduce its GHG emissions. ${ }^{179}$ This does not suggest a full application of the polluter-pays principle, but only its application at the margins in order to foster any possible reductions that a state can realistically realize within any given period of time.

Moreover, climate change reparations need to be politically negotiated. Adjudication at the international level is unlikely, and, even if it occurred and led to a finding on reparations, compliance would be contingent on the goodwill of responsible states. The negotiation of climate change reparations needs to take place in highly unfavourable geopolitical settings, where the responsible states tend also to be the strongest diplomatic powers, while the states most affected are among the weakest nations. These geopolitical settings do not mean that climate change reparations are doomed: on the contrary, the experience of spontaneous reparations schemes for mass atrocities ${ }^{180}$ and the theories of

\footnotetext{
I77. Limitations of reparations for historical emissions could also partly be justified in relation to the characterization of states' obligations under the no-harm principle. If the no-harm principle only gives rise to a due diligence obligation, state responsibility should not arise in relation to excessive GHG emissions which predate the emergence of a scientific consensus on the anthropogenic cause of climate change. See discussion in Mayer, supra note 8, para. 25.

I78. Robert E. GOODIN, "Selling Environmental Indulgences” (I994) 47 Kyklos 573 at 575 .

179. This might appear as an extraordinarily unambitious objective, except that it is already well beyond the current agreements or negotiations.

I 80. See, for instance, Luxembourg Agreement, supra note 87; and, more generally, Barkan, supra note I76.
} 
"policy entrepreneurship" ${ }^{\mathrm{I} 8 \mathrm{I}}$ or "norm entrepreneurship" ${ }^{\mathrm{8} 82}$ all suggest that it is possible for relatively weak but astute and well-organized advocacy coalitions to successfully claim for just and strong causes. If climate change reparations are to contribute to fostering efforts to avoid cataclysmic climatic change, however, timing is clearly of the essence. The current workstream on loss and damage could initiate such considerations within the climate regime, although any idea of reparation has continuously faced the fierce opposition of industrial states.

In order to facilitate the prompt negotiation of climate change reparations, one needs to identify possible areas of trade-offs and conceivable second-best deals. Climate change reparations have a restitutive function consisting in repairing a harm caused through a wrongful act (i.e. the impacts of anthropogenic climate change, resulting from excessive GHG emissions), and an instrumental function of promoting the cessation of the continuing wrong (the failure of numerous states to prevent excessive GHG emissions). As argued above, the instrumental function is by far the most urgent: from a pragmatic perspective, it is more crucial to prevent further harm than to advocate for compensation for the harm already caused. ${ }^{\text {I }} 3$ The most urgent remedy to a creeping crisis such as climate change should ensure or incentivize the prompt cessation of the harmful conduct, namely through climate change mitigation. A second-best climate change reparations regime should accordingly seek to provide an adequate economic and political signal for climate change mitigation policies, while avoiding as far as possible imposing additional costs onto the states most affected by climate change. It should only extend to providing material reparations as far as necessary in order to constitute an incentive for climate change mitigation.

Beyond material reparations, however, significant measures of satisfaction should constitute an integral part of any climate change reparations regime in order to reinforce a political signal for climate change mitigation. Symbolic measures such as a clear acknowledgment of responsibility, an apologetic attitude of relevant states officials, and a policy of memory-including through education to climate change, ${ }^{\mathrm{I} 84}$ efforts to raise public awareness, or even, for instance, the construction of museums-could play a great role in triggering a necessary questioning of the unsustainable development model that led virtually every state to fail to take adequate measures to protect the global environment. Material reparation and symbolic measures would be mutually reinforcing, as symbolic measures would be perceived as insincere if they were not accompanied by some measure of material reparations, while

I8I. Caner BAKIR, "Policy Entrepreneurship and Institutional Change: Multilevel Governance of Central Banking Reform" (2009) 22 Governance 57I; Michael MINTROM and Phillipa NORMAN, "Policy Entrepreneurship and Policy Change" (2009) 37 Policy Studies Journal 649.

I 82. Martha FINNEMORE and Kathryn SIKKINK, "International Norm Dynamics and Political Change" (I998) 52 International Organization 887; Ian JOHNSTONE, "The Secretary-General as Norm Entrepreneur" in Simon CHESTERMAN, ed., Secretary or General: The UN Secretary-General in World Politics (Cambridge: Cambridge University Press, 2007), I23; Lesley WEXLER, "The International Deployment of Shame, Second-Best Responses, and Norm Entrepreneurship: The Campaign to Ban Landmines and the Landmine Ban Treaty" (2003) 20 Arizona Journal of International and Comparative Law 56I.

I83. See Section II.C.

I 84. See e.g. UNFCCC, supra note Iо, art. 6(a)(i); Kyoto Protocol, supra note Io, art. Io(e); and decision I9/ CP.20, "The Lima Ministerial Declaration on Education and Awareness-raising" (2OI4). 
material reparations alone might not provide a sufficiently clear political signal without some symbolic expression.

\section{B. Implications for General International Law}

The previous reflection should also question the way reparations are thought of in general international law. More specifically, it suggests that there are exceptions to the general norm, identified by the International Law Commission, according to which " $[t]$ he responsible State is under an obligation to make full reparation for the injury caused by the internationally wrongful act". ${ }^{185}$ These exceptions are not by nature confined to leges speciales applicable to distinct fields: they are of a general nature, applying to analogous situations across diverse fields of international law. These exceptions include the "legal principle of general application", as identified by the ILC itself in its first reading of the Draft Articles on State Responsibility, according to which measures of reparation should not "result in depriving the population of a State of its own means of subsistence". ${ }^{86}$ But beyond the capacity of the responsible state to pay, a diminution of reparation could also be justified on grounds such as the indirect nature of the injury, the significant disproportion between the injury and the wrongfulness of the act, or the limitation of collective responsibility as a form of "rough" justice in cases of large injuries.

In addition, the example of climate change shows that technological advances as well as our improving understanding of complex causal relations make it increasingly likely that mere inadvertence or possibly wilful commission of mass atrocities are identified as the cause of catastrophic loss and damage, which challenges the assertion of a one-size-fits-all obligation to make full reparation. It is important that international law and its doctrine be prepared to deal with such cases. International jurisdictions should be given a certain leeway for an equitable assertion of remedial obligations, taking account not only of the extent of the injury, but also of the resources and the "culpability" of the responsible state, and of the opportunity of imposing costly reparations onto the population of that state, given its particular political circumstances. Moreover, as international law also plays a role as a source of legitimacy in international relations, the affirmation of an unconditional obligation to make full reparations could encourage claims that are morally excessive or politically unrealistic, and in any case unlikely to be met. In fine, these claims are most likely going to lead to severe international tensions between nations and hinder international negotiations, thus defeating the main purposes of international law. ${ }^{\text {I87 }}$

In a somewhat philosophical sense, one may actually doubt whether any reparation can be full, at least when the injury is not limited to purely material, fungible goods. Loss of lives, environmental damage, or loss of unique or irreplaceable properties can simply not be fully made up for. ${ }^{\mathrm{I} 88}$ In this perspective, reparation is rarely, if ever, able

I 85. Draft Articles on State Responsibility, supra note I2, art. 3 I(I).

I 86. First Reading of the Draft Articles on State Responsibility, supra note 73, commentary under art. 48 , at para. 8(a).

I 87. See, in particular, UN Charter, supra note I32, art. I.

I 88. See e.g. B.E. ALLEN, "The Use of Non-pecuniary Remedies in WTO Dispute Settlement: Lessons from Arbitral Practitioners" in M.E. SCHNEIDER and J. KNOLL, eds., Performance as a Remedy: NonMonetary Relief in International Arbitration (Huntington: Swiss Arbitration Association and Juris, 
to "wipe out all the consequences of the illegal act" ${ }^{89}$ or to make the injured party "whole"; ${ }^{190}$ rather, its objective is essentially to minimize the damage caused ${ }^{191}$ and to deter further breaches of international law. As Dinah Shelton once argued, notions such as full reparation "do not facilitate decision making by tribunals or claims practice of parties because they are too general to provide practical guidance". ${ }^{192}$ The nature of remedial obligations relates not only to the ambit of reparation, but also to its form. The assertions of remedial obligations should not be limited to an automatic assessment of the possibility of restitution, compensation, or measures of satisfaction, or to the determination of the quantum of reparations based on the valuation of the injury: it requires a more flexible decision based on a careful and detailed appraisal of the case.

\section{CONCLUSION}

Responsibility and reparation in international law fulfil two concomitant functions: addressing an injury and sanctioning a wrongful act. ${ }^{193}$ The principles recognized in positive international law, including the principle that a responsible state is obligated to make full reparation, were identified by international jurisdiction, often in cases regarding a relatively minor injury that could have significant consequences, in particular in the symbolic sphere, in the relation between states. In turn, efforts at codifying the law of state responsibility, in particular in the work of the International Law Commission, often took the limited practice of international jurisdiction as the basis on which to develop rules of general applicability.

Thus, relatively little importance was given to the need for different rules to apply to atypical cases, such as those involving large-scale damage, ${ }^{194}$ especially when they resulted from mere negligence as opposed to wilful acts, or when the responsible state was unable or otherwise unlikely to make full reparation. International jurisdictions were not always insensitive to the dangers of indicating measures of reparations that would probably not be complied with, and which could fuel geopolitical tensions, but they often preferred to disguise such considerations on other grounds. ${ }^{195}$ As technological advances make claims for large-scale reparations increasingly likely,

20II), 28I at 299; Summary Records of the 2399th meeting of the International Law Commission, UN Doc. A/CN.4/SR.2399 (I995), at para. 24.

I 89. Factory at Chorzów, P.C.I.J. Ser. A No. I7, at 47.

190. Opinion in the Lusitania Cases, decision of I November I923, VII Reports of International Arbitral Awards 32, 39: "The remedy should be commensurate with the loss, so that the injured party may be made whole."

I9I. See S. SHARPE, “The Idea of Reparation” in G. JOHNSTONE and D.W. van NEES, eds., Handbook of Restorative Justice (Cullompton: Willan, 2007), at 26.

192. D. SHELTON, "Righting Wrongs: Reparations in the Articles on State Responsibility" (2002) 96 American Journal of International Law 833 at 845 .

I93. See supra note I49.

194. See, however, Tomuschat, supra note 84 at 293. Tomuschat noted that, in the determination of war reparations, "account was always taken of the actual capacity to pay".

195. On the case of Application of the Convention on the Prevention and Punishment of the Crime of Genocide, see supra note $\mathrm{I} 3 \mathrm{I}$. 
doctrinal theories need to be developed regarding the limitation of the obligation to make full reparation.

Discussions on the nature of climate change reparations are prone to contribute to such doctrinal developments. Full reparation, in the context of climate change, is not only politically unrealistic and possibly toxic to friendly relations among nations. In addition, the indeterminacy of applicable remedial obligations and the spectre of demands for full or otherwise expansive reparation schemes have literally blocked any explicit recognition of responsibility by industrial states. Because the risks of admitting responsibility were too high, Western leaders have often turned to an attitude of denial — denying either any scientific evidence of anthropogenic climate change, or (hardly more subtly) any form of "fanatic" finger-pointing ${ }^{196}$ and any ground for specific obligations of industrial states in relation to climate change.

As the concept of loss and damage is gaining momentum in international climate change negotiations, and negotiating powers are shifting in favour of emerging economies and developing states generally, a window of opportunity might be opening for industrial states to acknowledge their responsibilities and to grant some form of reparation, thus providing a strong economic and political signal for climate change mitigation. In this process, however, the relevance of the international legal principle of responsibility in the context of climate change can only be advanced on the basis of a nuanced understanding of the applicable remedial obligations, admitting valid grounds for a reasonable diminution of reparations. Concerning a continuing wrongful act with the most alarming consequences for civilization and mankind, climate change reparations should first and foremost be designed to provide a strong incentive in favour of a prompt reduction of GHG emissions.

I96. US Senate, I05th Cong., I 43 Cong. Rec. S8I I7 (25 July I997). Senator Byrd also proclaimed: "the time for pointing fingers is over." The present paper is an argument about how to bring the time for pointing fingers to an end, through a reasonable offer of reparations. 